\title{
Noggin-mediated antagonism of BMP signaling is required for growth and patterning of the neural tube and somite
}

\author{
Jill A. McMahon, ${ }^{1}$ Shinji Takada, ${ }^{1,4}$ Lyle B. Zimmerman, ${ }^{3,5}$ Chen-Ming Fan, ${ }^{2}$ Richard M. Harland, ${ }^{3}$ \\ and Andrew P. McMahon ${ }^{1,6}$ \\ ${ }^{1}$ Department of M olecular and Cellular Biology, The Biolabs, Harvard University, Cambridge, Massachusetts 02138, USA; \\ ${ }^{2}$ Department of Embryology, Carnegie Institution of Washington, Baltimore, Maryland 21210 USA; ${ }^{3}$ Department of \\ Molecular and Cell Biology, University of California, Berkeley, California 94720 USA
}

\begin{abstract}
Embryonic patteming in vertebrates is dependent upon the balance of inductive signals and their specific antagonists. We show that N oggin, which encodes a bone morphogenetic protein (BMP) antagonist expressed in the node, notochord, and dorsal somite, is required for normal mouse development. Although $\mathrm{N}$ oggin has been implicated in neural induction, examination of null mutants in the mouse indicates that $N$ oggin is not essential for this process. However, Noggin is required for subsequent growth and patteming of the neural tube. Early BMP-dependent dorsal cell fates, the roof plate and neural crest, form in the absence of Noggin. However, there is a progressive loss of early, Sonic hedgehog (Shh)-dependent ventral cell fates despite the normal expression of Shh in the notochord. Further, somite differentiation is deficient in both muscle and sclerotomal precursors. Addition of BMP2 or BMP4 to paraxial mesoderm explants blocks Shh-mediated induction of Pax-1, a sclerotomal marker, whereas addition of Noggin is sufficient to induce Pax-1. Noggin and Shh induce Pax-1 synergistically. Use of protein kinase A stimulators blocks Shh-mediated induction of Pax-1, but not induction by Noggin, suggesting that induction is mediated by different pathways. Together these data demonstrate that inhibition of BMP signaling by axially secreted Noggin is an important requirement for normal patteming of the vertebrate neural tube and somite.
\end{abstract}

[Key Words: Noggin; somite; neural tube; patterning]

Received December 5, 1997; revised version accepted M arch 16, 1998.

Patterning of the vertebrate body axes is dependent upon signals produced by discrete organizing centers. Perhaps the best studied of these is Spemann's organizer, which encompasses the dorsal lip of the blastopore in the gastrulating amphibian embryo. Organizer signaling is implicated in dorsalization of both mesodermal and ectodermal derivatives. Dorsalization of the mesoderm leads to notochord and somite formation, whereas the dorsalized ectoderm forms neural tissue (for review, see Kessler and Melton 1994; De Robertis and Sasai 1996; Harland and Gerhart 1997). Four signals have been described that are expressed within the organizer and that have dorsalizing activity: Noggin (Smith and Harland 1992), Follistatin (Hemmati-Brivanlou et al . 1994), Chordin (Sasai et al. 1994), and Frzb (Leyns et al. 1997; Wang et al. 1997). N one of these share identifiable sequence similarity, but there is evidence to suggest that the first

Present addresses: ${ }^{4} \mathrm{Center}$ for Molecular and Developmental Biology, Faculty of Science, Kyoto University, Sakyo-ku, Kyoto 606-01, Japan; ${ }^{5}$ Department of Biology, The University of Virginia, Charlottesville, Virginia 22901 USA.

${ }^{6}$ Corresponding author.

E-MAIL amcmahon@biosun.harvard.edu; FAX (617) 496-3763. three may act by blocking bone morphogenetic protein (BM P) signaling.

N oggin binds several BM Ps with very high (picomolar) affinities, with a marked preference for BM P2 and BM P4 over BM P7. By binding tightly to BM Ps, N oggin prevents BM Ps from binding their receptors (Zimmerman et al. 1996). Chordin also antagonizes BMP signaling by directly binding BM $\mathrm{P}$ proteins, thereby preventing receptor activation (Piccolo et al. 1996). Follistatin binds to Activins, thereby preventing Activin signaling (N akamura et al. 1990). This antagonism extends to the more distantly related BMPs with a preference for BMP7 over BM P4 (Y amashita et al. 1995; Liem et al. 1997). Thus, a key function of these peptides is to antagonize signaling by distinct members of the TGF- $\beta$ superfamily.

Examination of postgastrulation stage Xenopus embryos indicates that some of these signaling factors are expressed at later stages. For example, Noggin is expressed in the notochord and dorsal neural tube, suggesting a possible role in the central nervous system (CNS) and somite patterning (Smith and Harland 1992); and in the chick, Noggin expression in the dorsal lip of the somite has been implicated in the control of myogenesis 
(Marcelle et al. 1997; Reshef et al. 1998). We have addressed the role of Noggin in mouse development. Noggin is not essential for neural induction but is required for normal growth and patterning of the neural tube and somite. Thus, inhibition of endogenous BMP signaling by $\mathrm{N}$ oggin is essential for elaboration of the vertebrate body plan.

\section{Results}

\section{Cloning and expression of $\mathrm{N}$ oggin}

We isolated a genomic clone that encodes the entire mouse Noggin polypeptide on a single exon (GenBank accession no. U 79163). The predicted protein contains 232 amino acids ( 25 kD) and shares 99\% and 80\% amino acid identity with the human (Valenzuela et al. 1995) and Xenopus (Smith and Harland 1992) proteins, respectively.

Noggin expression was examined in developing mouse embryos by whole-mount and section in situ hybridization. Embryonic expression was first detected in the node at 7.5 days postcoitum (dpc; arrowed in Fig. 1A). By early somite stages, Noggin expression extended anteriorly al ong the entire length of the notochord (large arrow in Fig. 1C), a similar pattern to the notochordal marker Brachyury (Fig. 1D). In addition, Noggin was expressed in the dorsal neural tube from the caudal hindbrain to the posterior-most region of the embryo (small arrows in Fig. 1C). By the time cranial neural tube closure was completed ( $9.0 \mathrm{dpc}$ ), N oggin expression was continuous along most of the dorsal midline of the neural tube (the roof plate), to its rostral termination at the base of the forebrain (Shimamura et al. 1995; small arrows in Fig. 1E). In contrast to Brachyury (Fig. 1G), expression in the notochord was not uniform but decreased rostrally at this stage (Fig. 1E). Expression in the neural tube and caudal notochord remained essentially unchanged during early organogenesis, from $9.5 \mathrm{dpc}$ (Fig. $1 \mathrm{H}, \mathrm{L})$ to 10.5 dpc (data not shown). We al so observed weak expression in the dorsal lip of the most rostral somites from $9.5 \mathrm{dpc}$ (arrow in Fig. $1 \mathrm{H}, \mathrm{J}$ ). Expression in the somite contrasts with the chick in which Noggin is strongly expressed even in the most recently formed somites (M arcelle et al. 1997; Reshef et al. 1998). Finally, Noggin was expressed in the rostral sclerotome at $10.5 \mathrm{dpc}$ (data not shown), coincident with the initial stages of cartilage condensation.

\section{Generation of N oggin mutants}

Experiments in a variety of vertebrates have demonstrated the importance of signaling by the node, notochord, and dorsal neural tube in patterning mesodermal

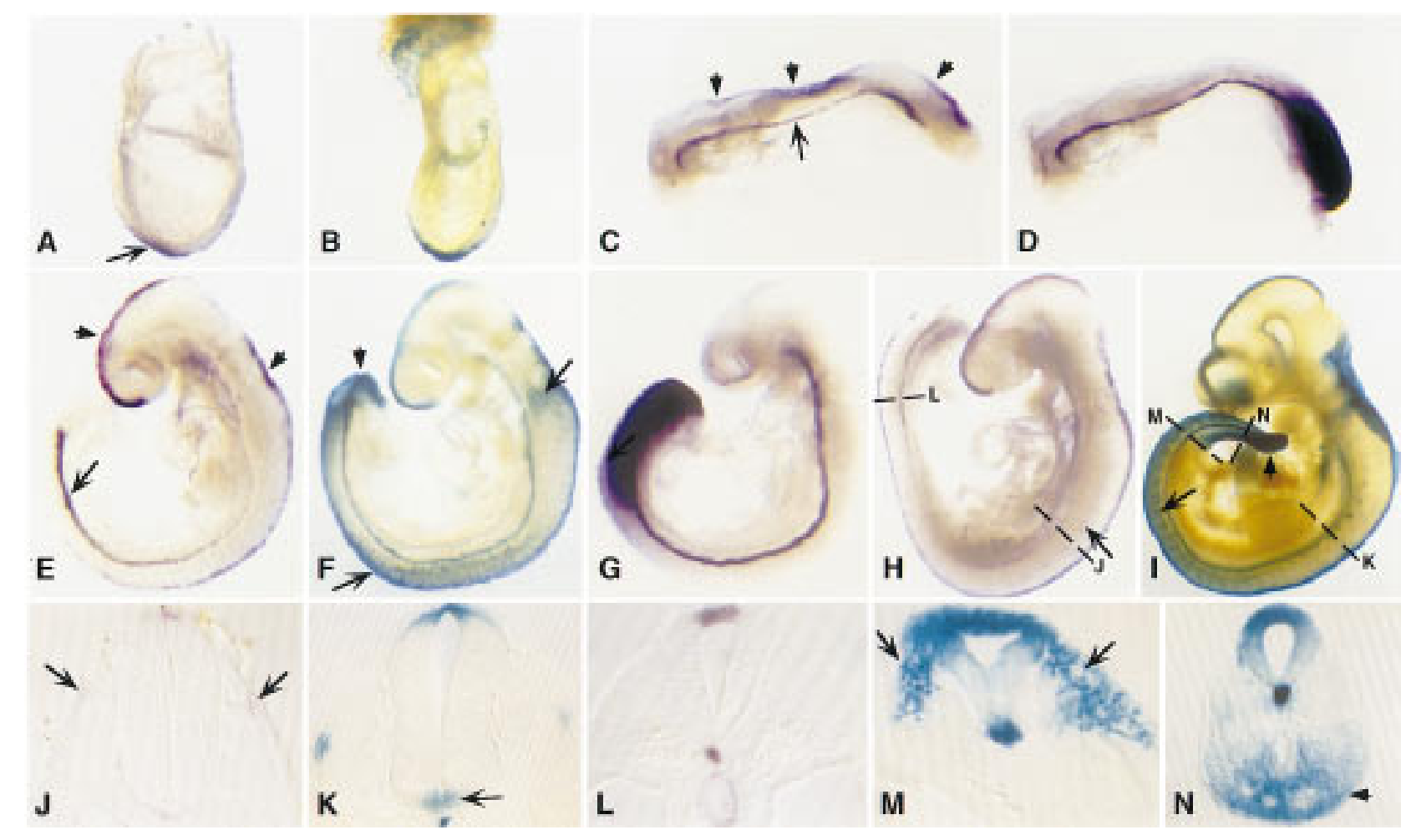

Figure 1. Expression of Noggin during mouse development. (A,C,D,E,G,H,J,L) Whole mount in situ hybridization with Noggin $(A, C, E, H, J, L)$ and brachyury $(D, G)$ probes; $(B, F, I, K, M, N) \beta$-gal actosi dase activity in embryos heterozygous for a targeted al lel e of $N$ oggin in which Noggin coding sequences were replaced by the lacZ gene. (A) $7.75 \mathrm{dpc}$ (B) $7.5 \mathrm{dpc}$ (C,D) $10 \mathrm{somites}(8.5 \mathrm{dpc}) ;(\mathrm{E}-\mathrm{G}) 9.5 \mathrm{dpc}$; $(\mathrm{H}, \mathrm{I}) 10 \mathrm{dpc}-10.5 \mathrm{dpc}$; $\mathrm{J}-\mathrm{N})$ transverse sections as indicated through embryos in $\mathrm{H}$ and $\mathrm{I}$. 
and neural tissues. To address the embryonic function of Noggin, we generated a null al lele by fusing the first 10 amino acids of the Noggin coding sequence to the lac $Z$ gene of Escherichia coli (Fig. 2A). The remainder of the coding sequence, and some $3^{\prime}$ flanking sequence, were deleted foll owing gene replacement at the Noggin locus (Fig. 2A). A correctly targeted CJ-7 embryonic stem (ES) cell clone was introduced into the mouse germ line and the mutant allel e was either outcrossed to the C57BL6/J strain or maintained on an inbred 129/Sv background.

Diagnostic Southern blot anal ysis with $5^{\prime}$ and $3^{\prime}$ flanking probes confirmed that the predicted targeted allele was present in Noggin mutants (Fig. 2B). Further, histochemical staining for $\beta$-gal actosi dase activity in heterozygous embryos confirmed that the lacz gene was expressed in the structures predicted from in situ hybridization studies (Fig. 1B,F,I,K,M ,N ). Weal so detected lacZ activity transiently in migrating neural crest cells (large arrows in Fig. $1 F, M$ ), in the dorsal root ganglia (a neural crest derivative, arrow in Fig. 1l), in ventral posterior mesoderm (small arrows in Fig. $1 \mathrm{~F}, \mathrm{I}, \mathrm{N}$ ), and in the rostral floor plate from $10.5 \mathrm{dpc}$ (large arrows in Fig. 1K). The expression in neural crest cells most likely reflected a perduring of $\beta$-galactosidase activity in neural crest cells emerging from Noggin expressing regions of the dorsal neural tube. A similar observation has been made in transgenic embryos which express lacZ under the control of the Wnt-1 enhancer (Echelard et al. 1994). However, expression in the ventral mesoderm and floor plate represent sites where N oggin transcripts are either below the level of detection by in situ hybridization, or where the lacZ gene was ectopically expressed. Ectopic expression could result from either the removal of $3^{\prime}$ flanking regions or from the influence of the PGK promoter.

\section{General N oggin phenotype}

Loss of Noggin resulted in a recessivelethal phenotype at birth. Superficial examination reveal ed multiple defects including a failure of neural tube closure, broad clubshaped limbs, loss of caudal vertebrae, a shortened body axis, and retention of a small vestigial tail (Fig. 3A-C). When examined on an inbred (129/Sv) or $F_{1}$ hybrid (129/ Sv; C57BL6/J) background, there was a pronounced variability in cranial neural tube closure. The brain was almost al ways open in N oggin mutants on the inbred background (Fig. 3B), but most often closed in mutants on the hybrid background (Fig. 3C).

To address the role that Noggin may play in events regulated by midline signaling we examined over 400
Figure 2. Gene replacement at the N oggin locus. (A) Schematic representation of gene replacement strategy in which most of the Noggin coding region was replaced by the lacZ gene of E. coli. (Top) Targeting construct that contains $5.2 \mathrm{~kb}$ of $5^{\prime}$ flanking sequence with lacZ fused in-frame to the first 10 amino acids of the Noggin coding exon (shaded), followed by a PGKneo cassette (neo; the arrow indicates the direction of transcription from the PGK promoter) and $5.0 \mathrm{~kb}$ of $3^{\prime}$ flanking homology starting at the BamHI site, $1.0 \mathrm{~kb}$ downstream of the Noggin stop codon. An MC1-HSVTK (TK) cassette was included for negative selection. (Middle) The wildtype Noggin locus with the single Noggin coding exon (shaded). (Bottom) The map represents the expected targeted allele following gene replacement at the Noggin locus. The positions of diagnostic $5^{\prime}$ and 3' flanking Southern probes are indicated (hatched boxes) and relevant restriction sites used in genotyping are shown in bold. (B) A nalysis of N oggin genotypes. Southern blot analysis demonstrating the expected gene replacement at the Noggin locus and germ line transmission of the targeted allele. Homologous recombinants were identified by hybridizing $5^{\prime}$ and $3^{\prime}$ probes external to the targeting vector sequences to ge nomic DNA digested with BamHI and EcoRI, respectively. The $5^{\prime}$ probe detects a 7.5-kb wild-type and 10.0-kb targeted band and the $3^{\prime}$ probe a 5.8-kb wild-type and 7.5$\mathrm{kb}$ targeted band.
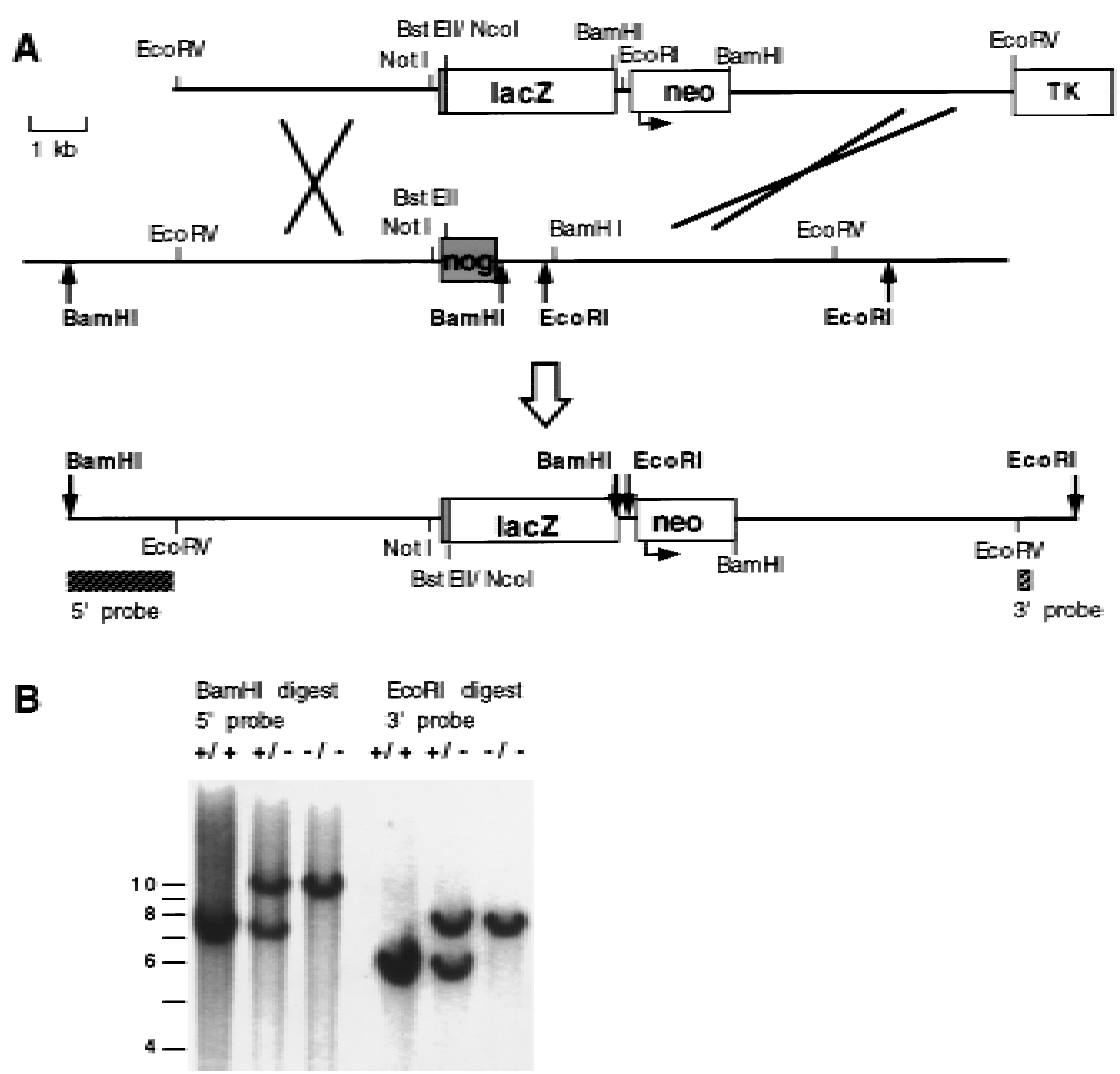
Noggin regulates CNS and somite development
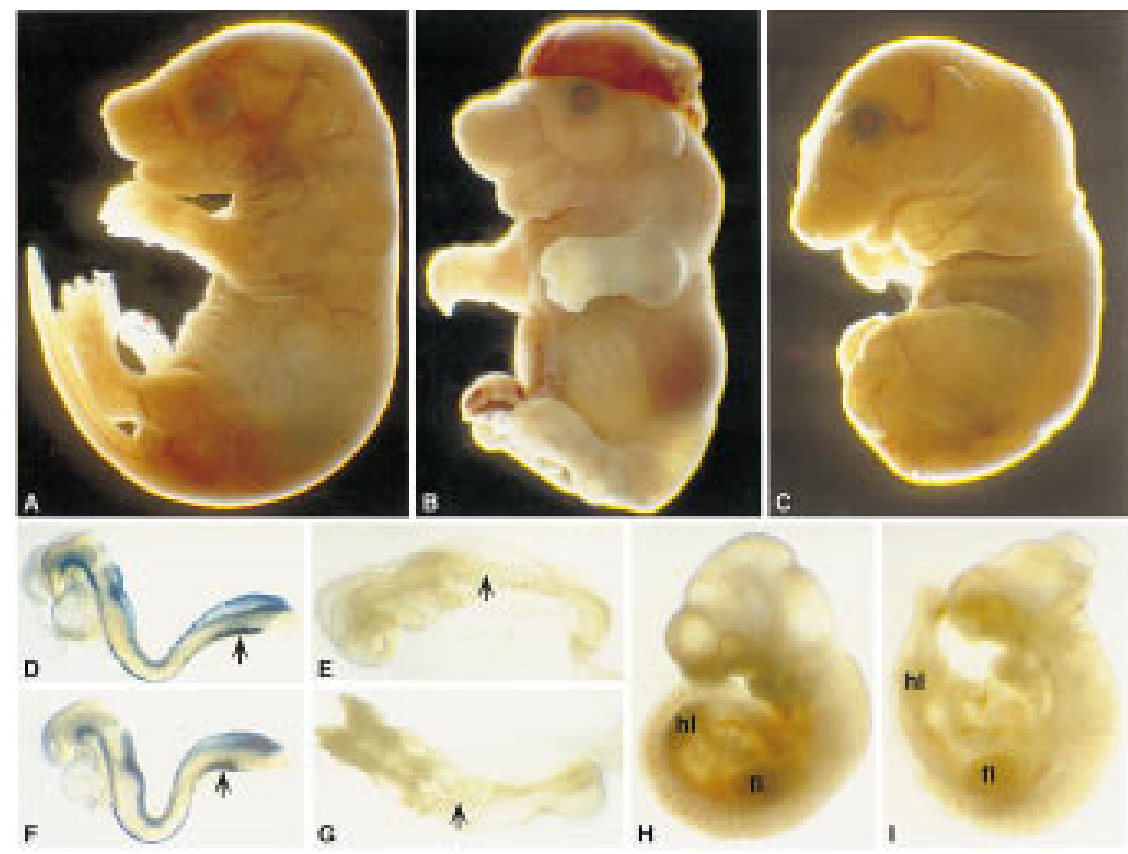

H

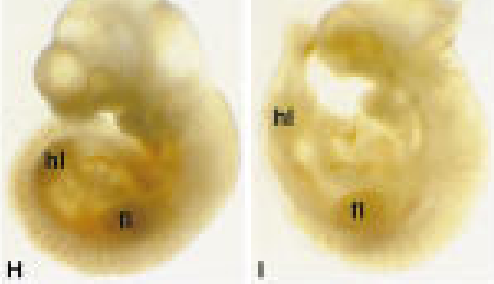

Figure 3. Superficial examination of Noggin mutant phenotype. (A,D,E,H) Wild-type; $(B, C, F, G, I)$ Noggin mutants at $18.5 \mathrm{dpc}(\mathrm{A}-\mathrm{C}), 8.5 \mathrm{dpc}$ (7-8 somites, $\mathrm{D}-\mathrm{F})$, $8.75 \mathrm{dpc}$ (12 somites, E-G), and $10.5 \mathrm{dpc}$ $(\mathrm{H}, \mathrm{I})$. Noggin mutants in $\mathrm{C}$ and $\mathrm{F}$ were on a 129/SV;C57BL6/J hybrid background; all others were on an inbred 129/Sv background. Embryos in D and F were stained to visualize lac $Z$ activity from the targeted allele at early somite stages. Forelimb (fl); hindlimb (hl). homozygous mutant embryos collected between $8.0 \mathrm{dpc}$ and $10.5 \mathrm{dpc}$ (from predominantly the 129/Sv background), for morphol ogy, histology, and gene expression. We report elsewhere on the function of Noggin at later stages in the control of cartilage morphogenesis (Brunet et al. 1998).

Staining for $\beta$-galactosidase activity at early somite stages revealed no difference in notochord or dorsal neural development between heterozygous and homozygous mutant embryos except for a slight shortening and broadening of the notochordal plate (arrowed in Fig. 3D,F). By the 8-9 somite stage, homozygous embryos on the 129/Sv background could be distinguished from wild-type or heterozygous siblings by a flattening of the elevating neural folds in the mid/hindbrain region (data not shown). Within the next few hours Noggin mutants on both backgrounds developed kinking of the spinal cord (arrows in Fig. 3E,G). A severe neural tube phenotype subsequently emerged. In the brain, the neural tube failed to close between the diencephal on and myelencephal on (129/Sv background) and was kinked along much of its length in presumptive spinal cord regions (both backgrounds; Fig. $3 \mathrm{H}, \mathrm{I}$ ). Occasionally the neural tube was open from the diencephal on to its caudal limit. The open and kinked brain perturbed eye and ear development but otherwise embryos appeared to develop fairly normally anterior to the forelimbs. In contrast, caudal to the forelimb, embryos exhibited a shortened axis, with the hindlimbs closer to the forelimbs; the tail was also short, and the somites and neural tube were considerably reduced in size (Fig. $3 \mathrm{H}, \mathrm{I}$ ).

Histological sections at different axial levels revealed a rostral to caudal increase in the severity of the Noggin phenotype. At the forelimb level, Noggin mutant embryos were essentially normal except for a distended dor- sal neural tube (Fig. 4A,B). At lumbar levels, the spinal cord and somites were significantly reduced in size and pockets of neural crest derived cells remained at the dorsal midline (Fig. 4C,D and large arrow in Fig. 5J). Extensive apoptosis was apparent at intermediate and ventral positions within the developing spinal cord (arrows in Fig. 4F). At caudal hindlimb levels, the decrease in neural tissue was more pronounced and the dorsal medial somite, which normally undergoes a mesenchymal transformation in forming the myotome, remained epithelial (arrows in Fig. 4H). A large mass of cells, most likely originating from the neural crest, lay immediately above the epithelial somite (Fig. 4G,H). Considerable cell death was evident in the ventral neural tube (data not shown). Interestingly, at extreme caudal positions, close to the tail bud, the neural tube, notochord, and presomitic mesoderm appeared similar to that of wild-type littermates, although discrete dorsal apoptosis was observed in the dorsal neural tube of mutants (Fig. 4l,J; data not shown). At $9.0 \mathrm{dpc}$, al though the neural tube was al ready considerably smaller, we could only detect apoptosis localized to the dorsal neural tube in thoracic regions (arrow in Fig. 4L). Thus, whereas Noggin does not appear to be essential for the formation of either mesodermal or neural tissue prior to $10.5 \mathrm{dpc}$, Noggin is required in caudal regions for normal development of both these tissues.

Noggin is required for ventralization of the posterior spinal cord

The expression of Noggin in the roof plate and notochord, both of which are organizing centers responsible for dorsoventral patterning of the vertebrate neural tube (Tanabe and Jessell 1996; Liem et al. 1997), suggests that Noggin may play some role in these events. Wetherefore 


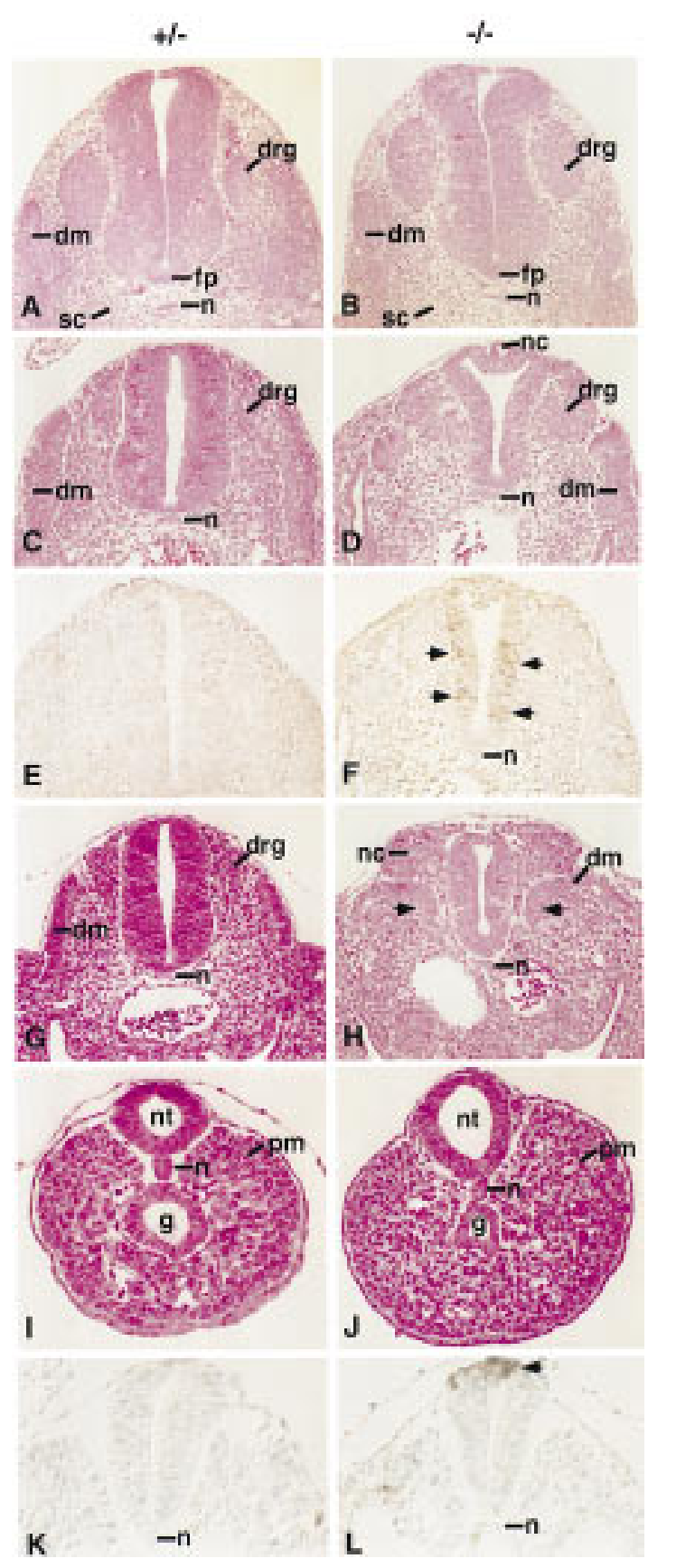

Figure 4. Histological and cell death analysis of spinal cord and somite development in Noggin mutants. Transverse sections through embryos heterozygous $(A, C, E, G, I, K)$ or homozygous $(B, D, F, H, J, L)$ for the targeted Noggin allele at $10.5 \mathrm{dpc}(A-J)$ and $9.0 \mathrm{dpc}(K, L)$. Sections were cut at the level of the forel imb $(A, B)$, between the fore and hindlimbs $(C-F, K, L)$, at the caudal hindlimb level $(\mathrm{G}, \mathrm{H})$, and through the presomitic mesoderm just anterior to the tail bud $(I, J)$. A-D and G-J are hematoxylin and eosin stained; $E, F, K$, and $L$ underwent the TUNEL reaction to visualize apoptotic cell death. Pairwise comparisons were photographed at the same magnification. (dm) Dermomyotome; (drg) dorsal root ganglia; (fp) floor plate; (g) gut; (n) notochord; (nc) neural crest; (nt) neural tube; (pm) presomitic mesoderm; (sc) sclerotome.

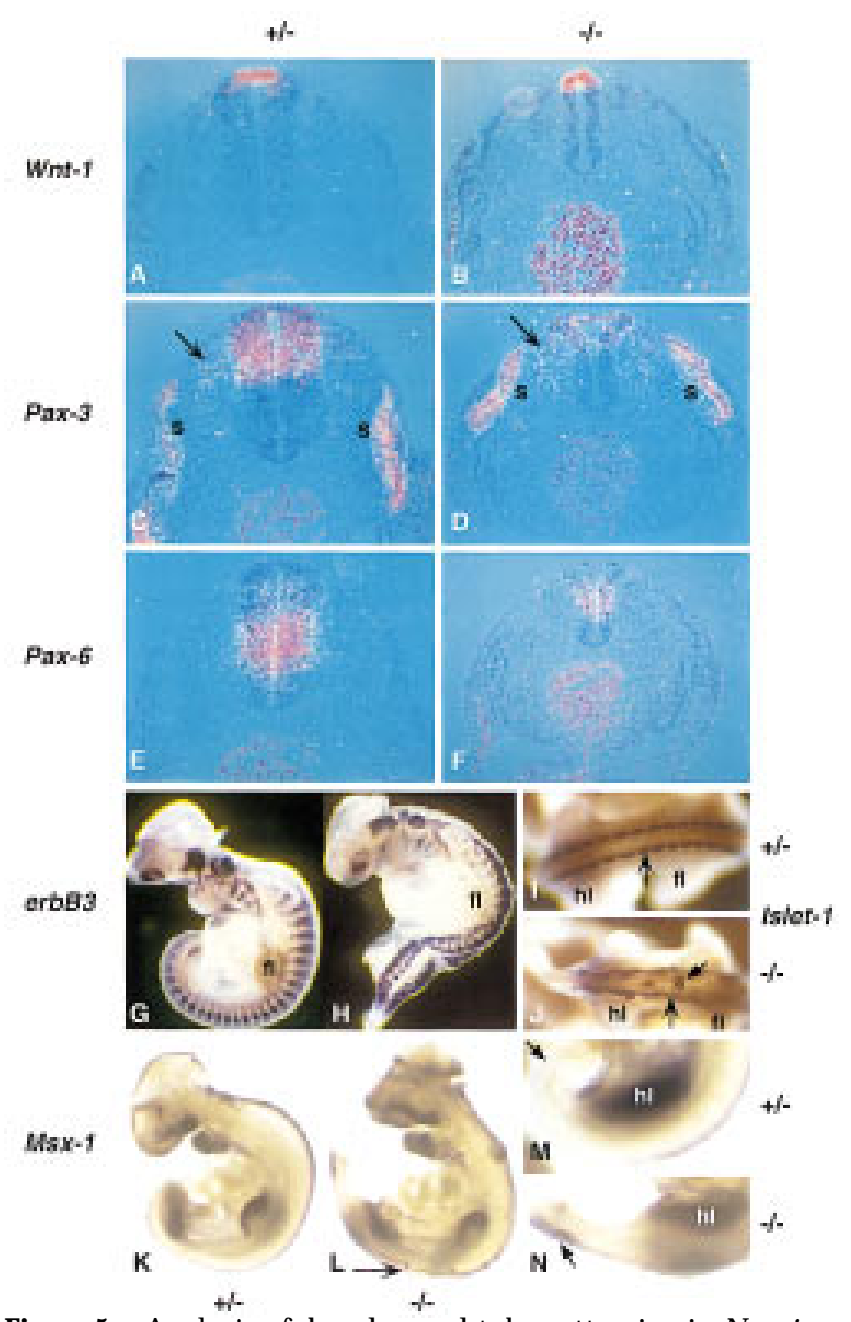

Figure 5. Analysis of dorsal neural tube patterning in Noggin mutants just rostral to the hindlimbs. Embryos heterozygous $(A, C, E, G, I, K, M)$ or homozygous $(B, D, F, H, J, L, N)$ for the targeted Noggin allele were examined at $10.5 \mathrm{dpc}$ by section $(A-F)$ or whole-mount (G-N) in situ hybridization for expression of Wnt-1 (A,B), Pax-3 (C,D), Pax-6 (E, F), erbB3 (G, H), Islet-1 (I, J), and $M$ sx- $1(\mathrm{~K}-\mathrm{N})$. The arrow in $\mathrm{L}$ indicates open neural tube in the lumbar region. (fl) Forelimb; (hl) hindlimb; (s) somite.

examined the expression of a number of molecular markers that define different dorsoventral positions in the early neural tube. To address dorsal development we examined the expression of the Noggin-lacZ fusion, Wnt1, Wnt-3a, Bmp-6, Lmx-1a, Msx-1, and Follistatin, all of which are expressed in the roof plate; Math1, which is also expressed just lateral to the roof plate; Pax-3, which is restricted to the dorsal hal $f$ of the spinal cord from the tail to the diencephal on; and Pax-6, which partially overlaps the ventral-most domain of Pax-3 expression, but extends into the ventral half of the neural tube. At 10.5 $\mathrm{dpc}$ all of these genes were expressed in their appropriate positions in the neural tube to hindl imb levels in Noggin mutants (Figs. 5A-F,K,L and 8S,T, below; data not shown). Thus, al though the presumptive spinal cord was clearly substantially reduced in size in the interlimb re- 
gion, the earliest features of positional specification in the dorsal half of the neural tube appeared to be unaltered. Further, migrating neural crest cells, which originate from the dorsal neural tube, and one of their derivatives, the dorsal root ganglia, could be identified by expression of the Noggin-lacZ fusion (data not shown), Pax-3 (arrows in Fig. 5C,D), erbB3 (Fig. 5G,H), and Isl et-1 (large arrows in Fig. 5I,J). However, migration and differentiation of the neural crest were disrupted, most likely as a result of defective neural tube closure (Fig. 4D,F) and abnormal somite development (see bel ow). Interestingly, Msx-1, unlike other roof plate markers, was ectopically activated in the most caudal neural tube of Noggin mutants (Fig. 5K-N ). As M sx-1 is a target of BM P4 signaling in neural tube explants in culture (Liem et al. 1995), this result suggests that $\mathrm{N}$ oggin may prevent the premature activation of this BMP target in the developing neural tube. In summary, although we detected increased cell death in undifferentiated regions of the dorsal neural tube, Noggin was not essential for most aspects of the initial steps of dorsal patterning we investigated. In contrast, the initial aspects of ventral ization of the posterior neural tube were abnormal in Noggin mutants.

A series of interactions are responsible for the induction of ventral cell fates (reviewed in Ericson et al. 1996, 1997; Tanabe and Jessell 1996). In the first of these, high concentrations of Sonic hedgehog (Shh) produced by the notochord induce the floor plate at the ventral midline. These cells coexpress Shh and the transcriptional regulator Hnf-3 $\beta$. Lower concentrations of Shh secreted by the notochord and floor plate induce the development of motor neurons ventrolaterally. Motor neurons or their progenitors express c-RET, Islet-1, Islet-2, Sim-1, and $\mathrm{N} k \times 2$ 2. . The exact pattern of marker gene expression and eventual cell fate is thought to depend on the concentration of Shh (Ericson et al. 1997). A nalysis of motor neuron deficient I slet-1 mutants suggests a second induction in which motor neurons induce Engrailed-1 (En-1) expressing interneurons (Pfaff et al. 1996); however, more recent evidence argues against a direct role for motor neurons (Ericson et al. 1997).

In wild-type embryos at $10.5 \mathrm{dpc}$, I sl et-1 (small arrows in Fig. 6A,C,E), Nkx2.2 (Fig. 6G), Sim-1 (barbed arrow in Fig. 8Q, below), and c-RET (data not shown) expressing differentiating motor neurons, and En-1 expressing ventral interneurons (arrow in Fig. 6l), extend to the hindlimb level. In contrast, in Noggin mutants motor neuron formation was greatly reduced between the limb buds (arrowhead in Fig. 6D) and was completely absent at hindlimb levels (Figs. 6F,H and 8R, below). Further, no En-1 expressing interneurons were detected caudal to the forelimbs (Fig. 6J). Surprisingly, expression of Shh in the floor pl ate (large arrow in Fig. 6K,L) and notochord (small arrow in Fig. 6K,L) appeared normal where the absence of ventrolateral neuronal populations was first apparent.

The phenotype was more severe at hindlimb levels where the spinal cord was markedly reduced in size. Here, Pax-3 was expressed throughout most of the spinal cord (data not shown), while Pax-6 expression was lost (Fig. 7A,B). At the ventral midline, only limited floor

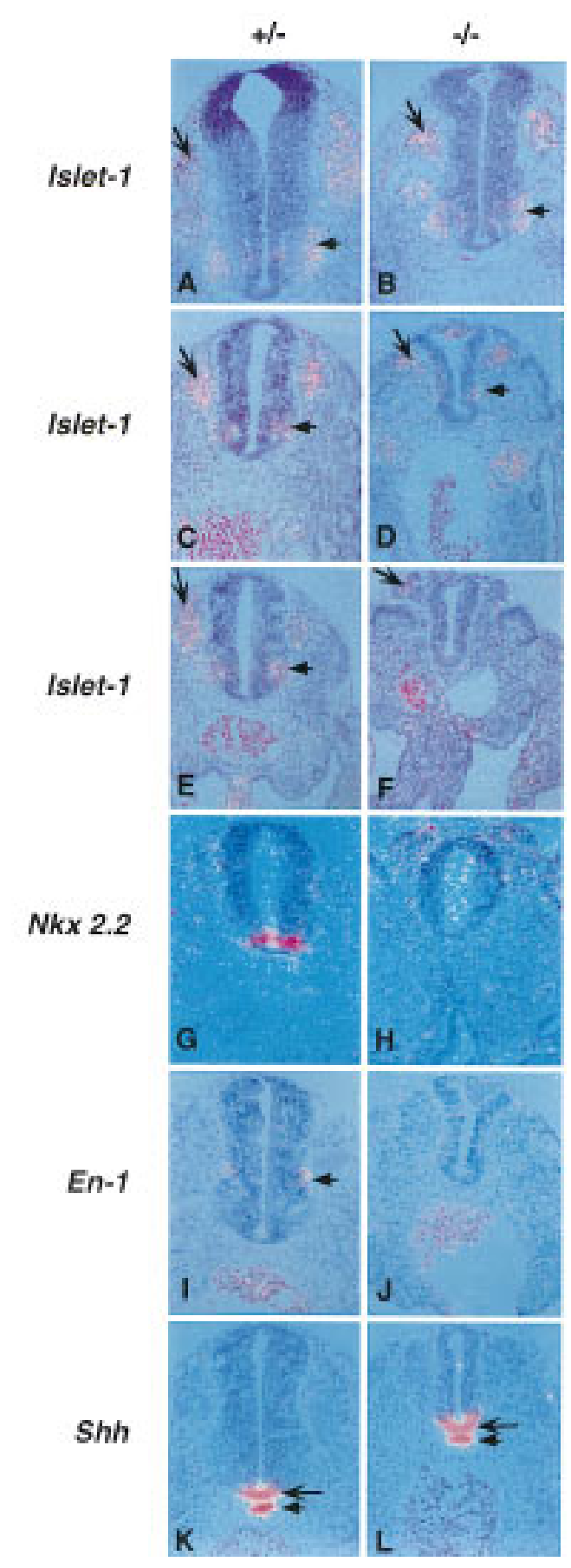

Figure 6. Failure of motor neuron and ventral interneuron development in the absence of N oggin. Section in situ hybridization at the level of the forelimb $(A, B)$, between the limbs $(C, D, G, J)$, and at the hindlimb (E-H) level in 10.5 dpc embryos heterozygous $(A, C, E, G, I, K)$ or homozygous $(B, D, F, H, J, L)$ for the targeted Noggin allele. Differentiating motor neurons or their precursors (short arrow) were detected with an Islet-1 probe (A-F), which also hybridizes to transcripts in dorsal root ganglia (barbed arrow) or with an Nkx2.2 probe $(\mathrm{G}, \mathrm{H})$. Differentiating ventral interneurons were detected by En-1 expression $(I, J)$, and notochord and floor plate by Shh (K,L). (For abbreviations, see legend to Fig. 5.) Pairwise comparisons were photographed at the same magnification. 


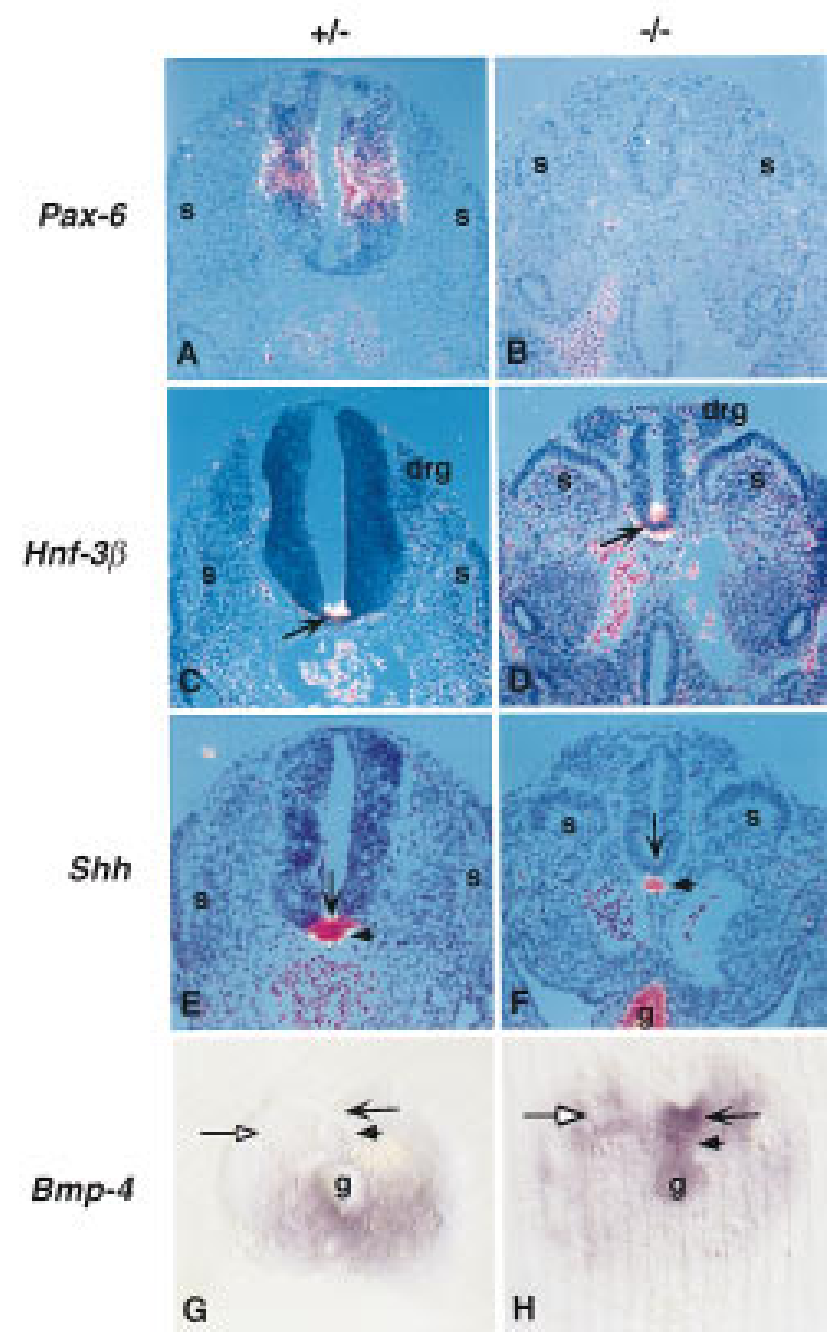

Figure 7. Development of the caudal neural tube in Noggin mutants. Section $(A-F)$ and whole-mount $(G, H)$ in situ hybridization of Pax-6 (A,B), Hnf-3B (C,D), Shh (E,F), and Bmp4 (G,H) probes to 10.5 dpc embryos heterozygous $(A, C, E, G)$ or homozygous $(B, D, F, H)$ for the targeted Noggin allele. (A-F) Hindlimb levels; $(G, H)$ tail region. Pairwise comparisons were photographed at the same magnification. (For abbreviations, see Fig. 5.)

plate development was apparent despite normal Shh expression in the notochord (small arrow in Fig. 7E,F). Hnf$3 \beta$ was induced (arrow in Fig. 7C,D) but no Shh expression was detected at the ventral midline of the neural tube (large arrow in Fig. 7E,F). These results indi cate that in the absence of N oggin, Shh is not sufficient for normal patterning of the ventral neural tube. However, Shh signaling appeared to be occuring, as Noggin mutants showed up-regulation of the Shh receptor and transcriptional target, Patched, in the ventral neural tube at all axial levels (data not shown).

As Noggin is a BMP antagonist (Zimmerman et al. 1996; Liem et al. 1997), and BM Ps have been implicated in dorsal neural patterning in spinal cord regions (Liem et al. 1995, 1997), we addressed the rel ationship between the expression of Bmp2-Bmp7 and caudal neural tube development in Noggin mutants. Unlike the chick, Bmp4 was not expressed in the dorsal neural tube but was expressed in the surface ectoderm (data not shown; Winnier et al. 1995; Dudley and Robertson 1997), coelomic epithelium underlying the neural tube and somites (data not shown), and ventral mesoderm (Fig. 7G) in the tail. Surprisingly, in the absence of $\mathrm{N}$ oggin we observed ectopic Bmp4 expression in the notochord (small arrow in Fig. $7 \mathrm{H}$ ) and at the ventral midline of the neural tube (large arrow in Fig. 7H) together with a dorsal expansion in the unsegmented mesoderm (open arrow in Fig. 7H), but only in the tail region. At more rostral positions no ectopic expression of any of the Bmps investigated was observed (data not shown). This suggests a transient role for Noggin in preventing Bmp4 activation in important ventralizing centers.

\section{Noggin is required for somite devel opment}

The requirement for Noggin in mesodermal development was addressed by examining embryos between 8.5 $\mathrm{dpc}$ and $10.5 \mathrm{dpc}$ of development. Although the notochord extended along the length of the axis to the tail bud at $10.5 \mathrm{dpc}$, it displayed occasional side branching and buckling in Noggin mutants. Shh, Hnf-3b, and Brachyury were expressed normally (Figs. 6L and 7F; data not shown), but there was a premature loss of lacZ activity in the rostral-most notochord of Noggin mutants suggesting that Noggin may be required for maintenance of its own expression (data not shown). Thus, Noggin is not required for either formation or early development of the notochord. However, after $10.5 \mathrm{dpc}$, tail development arrested and no new notochord was formed despite continued expression of the tail bud markers Brachyury, Wnt-3a, and Wnt-5a (data not shown). At this time Bmp4 expression was observed to extend into dorsal mesoderm (open arrow in Fig. 7H; data not shown). Whether this change in Bmp4 was responsible for the arrest of tail development is unclear. Expression of c-RET, Bmp7, and Sim-1 in the mesonephric duct (arrows in Fig. 8A,B; data not shown) was similar to wildtype littermates.

In the paraxial mesoderm, Noggin was not essential for segmentation but was required for growth and differentiation of the somite. Recent evidence indicates that somite patterning is governed by a complex network of signal s. For example, Shh signaling by the floor pl ate and notochord induces sclerotome formation (Fan and Tessier-Lavigne 1994; Johnson et al. 1994; Fan et al. 1995; Chiang et al. 1996). In the myotome, Shh and members of the Wnt family, which encode secreted glycoproteins, are implicated in muscle development Johnson et al. 1994; M unsterberg et al. 1995; Currie and Ingham 1996; Hammerschmidt et al . 1996a). As well as a requirement for certain signals for somite differentiation, recent evidence suggests that inhibition of BM P4 signaling may also play an important role in myotomal development (Reshef et al. 1998). Finally, dermal development is thought to depend on contact, mediated sig- 


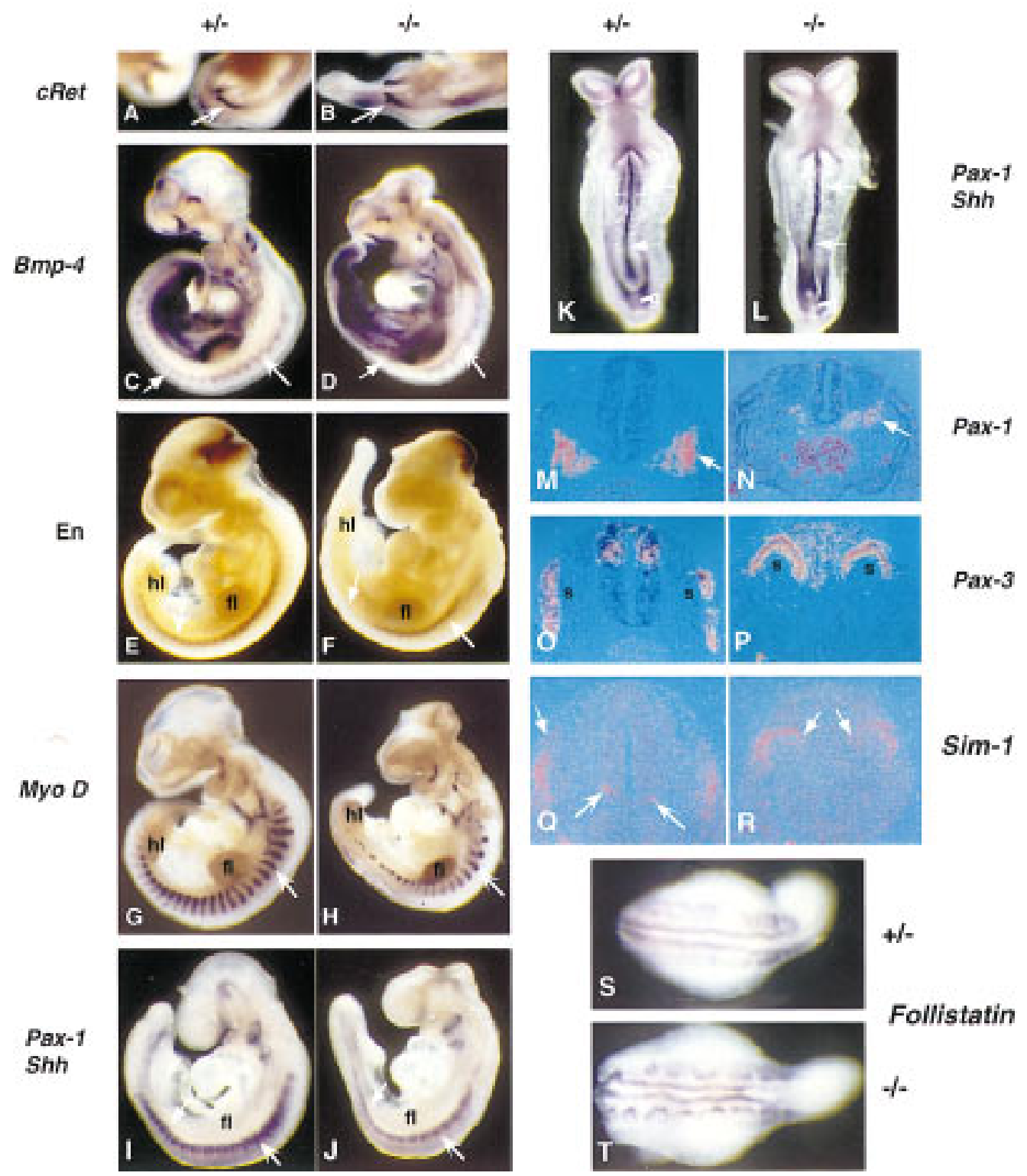

Figure 8. Somite devel opment is disrupted in Noggin mutants. Somite and ventral mesoderm devel opment was anal yzed in embryos at $8.5 \mathrm{dpc}(\mathrm{K}, \mathrm{L}), 9.5 \mathrm{dpc}(\mathrm{I}, \mathrm{J})$, and $10.5 \mathrm{dpc}(\mathrm{A}-\mathrm{H}, \mathrm{M}-\mathrm{T})$ by whole mount $(\mathrm{A}-\mathrm{L}, \mathrm{S}, \mathrm{T})$ or section $(\mathrm{M}-\mathrm{P})$ in situ hybridization using the markers indicated. Sections were probed at, or just rostral to, the level of the hindlimbs. Pairwise comparisons were photographed at the same magnification.

naling by the ectoderm (Fan and Tessier-Lavigne 1994), for which Wnt family members are strong candidates (Fan et al. 1997).

The development of somites originating rostral to the forelimb at 9.5 and $10.5 \mathrm{dpc}$ appeared grossly normal. In Noggin mutants the expression of Bmp4 (large arrows in Fig. 8 C,D; data not shown), En-1 (large arrows in Fig. $8 \mathrm{E}, \mathrm{F}$ ), Sim-1, and Pax-3 (data not shown) in the dermomyotome; myoD (arrows in Fig. 8G,H), myf5, and myogenin (data not shown) in the myotome; and Pax-1 (smal I arrows in Fig. 81,J), scleraxis, and Sox-9 in the sclerotome was similar to wild-type embryos. However, examination of early somite stages $(8.5 \mathrm{dpc})$ indicated that in the absence of N oggin, expression of the sclerotomal marker
Pax-1 was del ayed by several hours in these rostral-most somites (large arrows in Fig. 8K,L) despite normal Shh expression in the notochord (small arrow in Fig. 8K,L). Between the forelimbs and hindlimbs there was a more dramatic somitic phenotype; a severe reduction in both sclerotomal (small arrow in Fig. 8I,J,M,N) and myotomal, most strikingly dorsal myotomal (Fig. 8G,H), derivatives. Pax-3 expressing limb muscle precursors were present in mutants, even at hindlimb levels (data not shown). We al so observed an absence of dermomyotomal expression of Bmp4 (small arrow in Fig. 8D) and En-1 (small arrow in Fig. 8F), indicating that dermomyotomal differentiation was arrested. Interestingly, from the hindlimb caudal, the dorsomedial somite, where dorsal 
myotomal devel opment normal ly initiates, remained epithelial and continued to express the predifferentiation marker, Pax-3 (Fig. 80,P). Furthermore, Sim-1, whose ventrolateral dermomyotomal expression is thought to be regulated by BMP4 signaling (Pourquie et al. 1996), extended into the dorsomedial epithelial somite at the hindlimb level (arrows in Fig. 8R). Finally, Follistatin (which encodes an activin and most likel y BM P7 antagonist) appeared to be up-regulated in the dorsomedial somite of Noggin mutants (Fig. 8T). Together, the data indicate that $\mathrm{N}$ oggin-mediated antagonism of BM P signaling is essential for normal growth and patterning of the caudal somites.

Noggin is required for Shh-mediated induction of sclerotomal development

The substantial delay and reduction in sclerotomal and myotomal devel opment suggests that $\mathrm{N}$ oggi $\mathrm{n}$ may cooperate with Shh in patterning the somitic mesoderm. We therefore investigated whether Noggin is able to synergize with Shh in the induction of Pax-1 in presomitic mesoderm (psm) explants (Fan et al. 1995). The presence of N oggin reduced the threshold induction of Pax-1 by SHH-N fourfold (from 25 to $6.8 \mathrm{ng} / \mathrm{ml}$; Fig. 9A), indicating that $\mathrm{N}$ oggin synergizes with Shh. Surprisingly, high concentrations of N oggin $(>100 \mathrm{ng} / \mathrm{ml})$ were sufficient to activate Pax-1 (Fig. 9B). To determine whether the response to $\mathrm{N}$ oggin resulted either from potentiating low levels of Shh present in the psm, or from an early exposure to Shh signaling emanating from the notochord, we added antagonists that are known to abolish SHH-N function in this assay. Addition of a blocking antibody against SHH-N (Ericson et al. 1996), although able to inhibit SHH-N induction of Pax-1, did not block induction by $\mathrm{N}$ oggin (Fig. 9C). Furthermore, induction was not blocked by addition of IBMX and forskolin, which antagonize SHH-N signaling by elevating intracellular CAM P (Fig. 9C). Taken together, we conclude that N oggin can act al one to activate Pax-1 expression in the psm explant.

We next tested whether purified recombinant BM P2 or BMP4 can suppress Pax-1 induction. Both these BMPs were potent inhibitors. Ten nanograms/milliliter of either BMP completely abolished Pax-1 induction in response to Noggin, SHH-N , or a combination of the two (Fig. 9D). These results suggest that overcoming inhibitory BM P signaling is necessary to initiate the sclerotomal program. In the embryo, inhibitory BM Ps could be supplied by the paraxial mesoderm itself, or by adjacent tissue. In situ hybridization studies have demonstrated that the early somite uniformly expresses Bmp3 (Dudley and Robertson 1997; J. M cM ahon et al., unpubl.). Moreover, the somite forms adjacent to the notochord that expresses Bmp3 and Bmp7, above the ventral mesoderm that expresses Bmp4, and adjacent to the surface ectoderm that expresses Bmp4 and Bmp7 (Dudl ey and Robertson 1997; data not shown). In addition, using PCR, we explored the possibility that the psm may express low levels of Bmps not detectable by in situ hybridization.
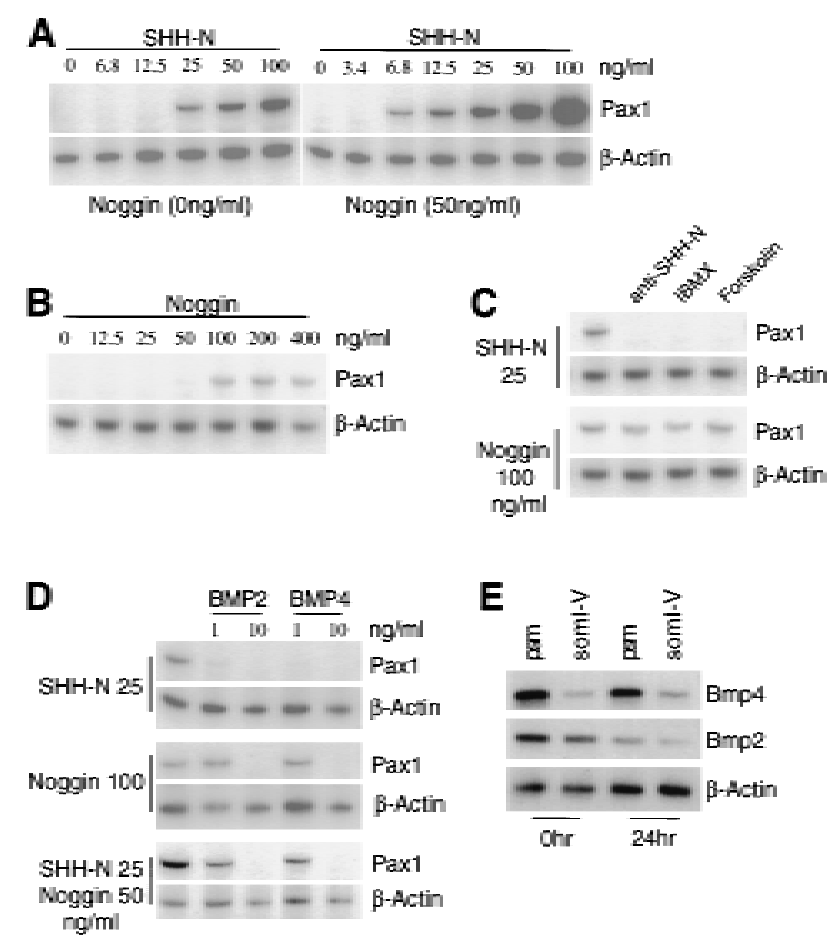

Figure 9. N oggin and Shh function synergistically to activate the expression of sclerotome marker Paxl in presomitic mesoderm. Mouse psm explants $(9.5 \mathrm{dpc})$ were cultured in collagen gels for $24 \mathrm{hr}$ in the presence or absence of purified recombinant N oggin, SHH-N (the amino-terminal 19-kD peptide), BM P2, or BM P4. The concentration of each of these is indicated. RNA samples from each culture (two pieces of psm per culture) were extracted and subjected to RT-PCR to assess marker gene expression. Expression of $\beta$-actin was assayed as a control for RN A recovery and CDN A synthesis (see M aterials and M ethods). (A) Psm explants were treated with a series of concentrations of $\mathrm{SHH}-\mathrm{N}$ (as indicated) with (right) or without (left) $50 \mathrm{ng} / \mathrm{ml}$ Noggin. Expression of the sclerotome marker Pax 1 and the $\beta$ actin control was assessed by RT-PCR. (B) N oggin alone can also activate the sclerotomal marker Paxl. (C) N oggin can induce Pax-1 expression in the presence of a SHH-N blocking antibody, IBM X, and forskolin, whereas all these reagents block SHH-N mediated induction of Pax-1 in psm explants. (D) Purified BMP2 and BMP4 protein can inhibit Pax-1 induction in response to $\mathrm{SHH}-\mathrm{N}, \mathrm{N}$ oggin, or a combination of each protein. (E) The psm and the five caudal-most somites (soml-V) were assayed immediately ( $0 \mathrm{hr}$ ) or after $24 \mathrm{hr}$ of culture ( $24 \mathrm{hr}$ ) for expression of Bmp2 and Bmp4 (30 cycles). RT-PCR products were analyzed by Southern hybridization (see $M$ aterials and $M$ ethods). $\beta$-actin (13 cycles) expression was similar in all samples.

After 30 cycles we detected Bmp2 and Bmp4 (Fig. 9E), but failed to detect Bmp5, Bmp6, and Bmp7 after 35 cycles. Although we cannot rigorously exclude the possible contamination by ventral mesoderm, these results suggest that the psm itself, or neighboring tissues, express those Bmps that are known to interact with $N$ oggin.

\section{Discussion}

N oggin and the organizer

Expression of Noggin in the organizer region of the Xeno- 
pus embryo (Smith and $\mathrm{Harland}$ 1992), and the results of ectopic expression studies in the frog (Smith and $\mathrm{H}$ arland 1992; Lamb et al. 1993; Smith et al. 1993) and fish (Hammerschmidt et al. 1996b) are consistent with Noggin playing a central role in specifying dorsal cell fates in both the ectoderm (neural plate) and mesoderm (somite and notochord). The recent demonstration that N oggin is a direct antagonist of ventralizing BMP signals suggests a simple mechanism by which Noggin patterns the embryo, through the graded inhibition of ventral BMP signaling (Zimmerman et al. 1996). However, even though Noggin is expressed in the mouse node, a structure with similar properties to the Xenopus organizer (Beddington 1994), Noggin is not essential for formation of neural tissue, notochord, or somites. Rather, our results demonstrate that Noggin expression in the notochord and roof plate plays a later role in somite and neural tube development.

No phenotype was observed in Noggin mutants until $8.5 \mathrm{dpc}$, despite the early midline expression of Noggin. There only appears to be a single Noggin gene in vertebrates, so it is unlikely that there is redundancy between Noggin and a second, unidentified family member. However, at least two unrelated secreted polypeptides, Follistatin and Chordin, have similar activities. Both of these are expressed in the early mesoderm and/or node of the gastrulating mouse embryo (Albano et al. 1994; E. De Robertis, pers. comm.). Follistatin null mutants show no defects in organizer function (Matzuk et al. 1995). Chordin mutants have been identified in the zebrafish (Schulte-Merker et al. 1997). One of these, dino, has a ventral ized phenotype consistent with some loss in organizer function (Hammerschmidt et al. 1996b). Consequently, it may be necessary to remove Noggin, Chordin, and Follistatin to completely uncover their putative organizer properties.

\section{N oggin and neural tube development}

Although Noggin does not play an essential role in the induction of neural tissue, it is required for subsequent development of the neural tube. In Noggin mutants, we observed a failure of neural tube closure in cranial and lumbar regions, a dramatic reduction in the amount of posterior neural tissue, and the progressive failure of ventral development in the posterior neural tube.

Noggin is expressed in the dorsal aspects of the neural plate, the presumptive roof plate, coincident with neural tube closure. Thus, it is possible that Noggin may play a direct role in regulating the cellular processes that lead to the el evation and fusion of the neural folds (for review, see Schoenwolf and Smith 1990). Examination of a large number of molecular markers expressed either in or around the closing neural tube (Wnt-1, Wnt-3a, Bmp6, Follistatin, Lmx-1a, Noggin-lacZ, Math1, Pax-3) failed to reveal any striking difference between Noggin mutants and wild-type siblings suggesting that the failure of neural tube closure does not appear to result from a clear defect in early patterning of the dorsal neural tube. However, we observed premature activation of a BM P4 target,
Msx-1, in the caudal neural tube, consistent with a role for $\mathrm{N}$ oggin in preventing Msx-1 activation. We also observed enhanced cell death at the dorsal midline of the neural tube in Noggin mutants. As Msx family members have been implicated in the regulation of apoptosis (e.g., Graham et al. 1994) there may be a correlation between these two observations. Furthermore, recent work suggests that regulation of cell death may play an important role in neural tube closure (Weil et al. 1997). Whether there is a link between deregulated cell death and the open neural tube remains to be explored but it seems likely that the Noggin mutants might provide a useful model for studying this important and poorly understood morphological process.

The other obvious CNS phenotype we observed is a reduction in posterior neural development that occurs secondarily to the formation of neural tissue. Caudal to the forelimbs there was a progressive decrease in the diameter of the neural tube that was accompanied by the appearance of extensive cell death, principally in intermediate and ventral regions of the developing spinal cord. Thus, Noggin appears to be required for survival, and possibly proliferation, of neural precursors in the neural tube. A reduction in the size of the neural tube is evident at both dorsal and ventral positions consistent with a role for Noggin in both the dorsal and ventral development. Dorsally, expression of all early regional markers investigated was appropriately positioned and extensive neural crest formation was observed. In vitro studies in the chick have demonstrated that several TGF- $\beta$ family members, including BMP4 and BMP7, may contribute to the induction of dorsal neurons. Furthermore, they suggest that blocking early BMP activity may be a prerequisite for the emergence of later arising dorsal cell fates (Liem et al. 1997). Whether specific dorsal neuronal populations that emerge later in development are dependent on Noggin function remains to be determined.

Surprisingly, Noggin is clearly essential for establishment of some ventral cell fates in the developing CNS. At posterior lumbar levels, motor neurons and ventral interneurons were depleted or entirely absent. In more posterior positions, floor plate development was initiated but a mature floor plate was not formed. Finally, caudal to the hindlimbs, much of the neural tube appeared to adopt a dorsal, l ikely neural crest cell fate. How might these results be explained in light of our understanding of growth and patterning of the neural tube?

There is now overwhelming evidence to support the conclusion that Shh signaling plays a key role in induction of two ventral cell fates in the vertebrate CNS, motor neurons and floor plate (for review, see Tanabe and Jessell 1996; Hammerschmidt et al. 1997). In Noggin mutants we observed a failure of motor neuron induction, despite the normal expression of Shh in both the floor plate and notochord, the two signaling centers implicated in motor neuron induction (Yamada et al. 1991; Placzek et al. 1991; Yamada et al. 1993). Thus, in the embryo proper, in the absence of N oggin, Shh is not sufficient for the normal specification of motor neuron 
fates. As in the Islet-1 mutant (Pfaff et al. 1996), in the absence of motor neuron fates, En-1 expressing ventral interneurons are al so missing. The loss of Pax- 6 expression in the ventral neural tube is also consistent with these results as motor neuron and interneuron fates arise from Pax-6 expressing neural precursors (Ericson et al . 1996, 1997). In more posterior regions, we also observed that although Shh expression in the notochord was sufficient to activate $\mathrm{Hnf}-3 \beta$ at the ventral midline of the neural tube, it was not sufficient to activate Shh itself, a normal feature of the floor plate. Finally, in the most posterior regions, no ventral development occurred even though Shh was expressed in the underlying notochord. Together, these results indicate that Noggin-mediated antagonism of BM P signaling is essential for Shh-mediated ventralization of the mouse neural tube. It is unlikely that Shh signaling is lost as we observed up-regulation of Patched transcription in the ventral neural tube as expected (data not shown). However, Shh signaling does not result in normal ventralization of the spinal cord.

Several lines of evidence support the view that BM Psignaling might prevent Shh action. For example, implantation of Bmp7 expressing cells adjacent to the mouse hindbrain blocks autoinduction of Shh in the floor plate (Arkell and Beddington 1997). Furthermore, addition of BM P4 Dorsalin-1, a TGF- $\beta$ family member, to neural tube explants strongly inhibits the motor neuron inducing activity (presumably Shh) produced by ventral axial structures (Basler et al. 1993). Thus, the response to ectopic BMPs in these assays resembles the phenotype resulting from loss of Noggin function. A localized requirement for Noggin may also explain why ectopic expression of Shh throughout the neural tube of the Xenopus embryo (Ruiz i Altaba et al. 1995), or at the mid/hindbrain junction in the mouse (Sasaki and Hogan 1994), only results in ectopic floor plate development adjacent to the roof plate where Noggin is expressed.

BM Ps, in particular BM P4 and BM P7, have been implicated in the induction of dorsal cell fates in presumptive spinal cord. The surface ectoderm most likely initiates dorsalization of the neural tube (Dickinson et al. 1994; Liem et al. 1995). The ectoderm expresses several BMPs and these appear to play a role in induction of dorsal cell fates (Basler et al. 1993, Liem et al . 1995, 1997; Dudley and Robertson 1997). Thus, in spinal cord regions, BM P signaling has an opposite function to that of Shh. Moreover, there is evidence to suggest that the neural plate is initially dorsalized, presumably in response to early acting BM P signals, and that ventral cell fate specification, which occurs later, requires the suppression of dorsal cell fates (Ericson et al. 1996). Our data show that for Shh to work effectivel y in the embryo, BM P signaling must be antagonized. The notochord expresses Bmp3 and Bmp7 (Dudley and Robertson 1997), suggesting that Noggin could play a direct role in antagonizing their activities. Although BM P3 binding to $\mathrm{N}$ oggin has not been tested, functional studies indicate that it is unlikely to have the same properties as BMP4 (K. Lyons, pers. comm.). However, Noggin does bind BM P7, al beit with considerably weaker affinity than for BMP4. Whether this has physiological significance in the embryo is difficult to assess. Follistatin, which binds BMP7 more strongly, is expressed normally in the roof plate of $\mathrm{N}$ oggin mutants. Alternatively, Noggin may prevent the spread of BMP4 from the ventral mesoderm, or the activity of low levels of Bmp2 or Bmp4 in the paraxial mesoderm. In keeping with this hypothesis, we observed the induction of Bmp4 in the notochord and at the ventral midline of the caudal neural tube in Noggin mutants. Thus, in the absence of Noggin, BM P4 in the ventral mesoderm may be able to induce its own expression in more dorsal regions.

The loss of ventral cell fates in Noggin mutants does not appear to be accompanied by a concomitant expansion of dorsal cell fates. Rather, it would appear that many ventral cells die. Intriguingly, this results in a gross reduction of the neural tube that appears to be more pronounced than that of notochord, deficient embryos (van Stratten and Hekking 1991; Yamada et al. 1991). Why should the loss of a single secreted polypepti de generate a more severe phenotype than the complete loss of all notochordal activities? One possible explanation is that in the absence of N oggin, ventral cells would receive conflicting signals since Shh is still produced and cells appear to respond to Shh. These conflicting signals, BM Ps (dorsalizing) and Shh (ventralizing), might cause cell death. Interestingly, in the forebrain Shh and BM Ps, most likely BM P7, have been proposed to collaborate in the patterning of ventral di encephalic regions (Dal e et al. 1997), suggesting that the combination of these signals might lead to the specification of diencephalic neural precurors in the spinal cord. However, we found no evidence for ectopic expression of N kx2.1 to support such a model (data not shown).

\section{N oggin and somite development}

In the absence of Noggin there is marked reduction in both the induction and survival of sclerotomal and myotomal derivatives in the trunk. A large body of evidence indicates that the distinct cell fates are generated within the epithelial somite in response to inductive cues from surrounding tissues (for review, see Brand-Saberi et al. 1996; Cossu et al. 1996). For example, removal of the notochord results in a failure of sclerotomal induction. In vitro, the inductive properties of the notochord are mimicked by Shh (Fan et al. 1995). However, Shh mutants exhibit some Pax-1 expression, indicative of limited sclerotomal development, which is followed by a secondary loss of these cells (Chiang et al. 1996). Thus, Shh is not essential for initiating all sclerotomal development. Our data suggest that Noggin contributes to sclerotomal induction.

First, Noggin is required at all axial levels for the normal induction of sclerotome. At rostral levels, induction is delayed but is otherwise normal, at thoracic levels the sclerotomal population is reduced, and at more posterior positions sclerotome is entirely absent. Second, at high concentrations Noggin induces sclerotomal development in the absence of Shh. Third, addition of Noggin to 
presomitic mesoderm explants lowers the effective dose of Shh which is required to induce sclerotome. Fourth, BM P2 and BM P4 are potent inhibitors of Pax-1 induction by Shh in culture. Moreover, grafts of BM P4-expressing cells inhibit growth and differentiation of the chick sclerotome (M onsoro-Burq et al. 1996). These findings can be explained by a simple model in which BMP signaling generally inhibits early somite differentiation. Countering this inhibition may be essential for sclerotomal induction. Binding of BMP4, and possibly other BM Ps, by Noggin would provide a direct antagonism. It is unlikely that BM P signaling inhibits Hedgehog targets by activating PKA (for review, see Hammerschmidt et al. 1997), as N oggin is still able to induce Pax-1 in the presence of PKA agonists.

The notochord and neural tube are also implicated in the induction of muscle derivatives that fail to develop when both tissues are removed (Rong et al. 1992). Shh also appears to play a role in myotome induction, most likely with dorsally expressed members of the Wnt family (M ünsterberg et al. 1995; Chiang et al. 1996). The loss of myotomal derivatives in Noggin mutants suggests that suppression of BMP signaling is also necessary to allow effective muscle induction. The somite gives rise to distinct populations of muscle precursors in different positions (Cossu et al. 1996). Myogenic gene expression occurs first in the dorsomedial component that gives rise to the epaxial musculature, then later in the ventrolateral hypaxial precursors. BM P4 is implicated in the regulation of distinct cell fate choices within the myotome. Bmp4 is expressed in the lateral mesoderm adjacent to the hypaxial precursors and application of BM P4 to the dorsomedial component leads to the repression of myogenic gene expression (Pourquie et al. 1995). In contrast, the formation of epaxial muscles from the dorsomedial somite requires an opposing activity, and this appears to arise from the dorsal neural tube during development (Pourquie et al. 1996). In the mouse, Noggin is expressed in the roof plate, then much later in development, Noggin is expressed rather weakly in the dorsal lip of the somite. Dorsomedial expression of Noggin is in general consistent with a role in antagonizing BM P signaling in the regulation of muscle patterning. In the chick, however, Noggin has more pronounced and earlier expression in the dorsal lip of the somite, and here expression in the somite may play a more direct role in controlling myogenesis (Reshef et al. 1998). In Noggin mutants we observed the loss of dorsal myogenic gene expression and a dorsal expansion of Sim-1, a marker of ventrolateral fates, into the dorsomedial dermomyotome at hindlimb levels. In contrast, Noggin is not required for formation of Pax-3-expressing limb muscle precursors at either the fore- or hindlimb levels (data not shown). We also observed an up-regulation of Follistatin in the dorsomedial somite suggesting that its expression may be positively regulated by dorsal BM P signaling. Thus, it is likely that N oggin antagonism of BM P signaling is required for both myotomal and sclerotomal development. However, the failure of dermomyotomal expression of En-1 points to a broader inhibitory role for BM Ps in the somite.
Whereas our results establish the principle of Noggin action, we cannot be certain as to the exact identity of the relevant targets. For example, the biochemical characterization of N oggin interactions has been restricted to a subset of BM Ps, but there are several other members of the TGF- $\beta$ family, notably some of the GDFs, which are also coexpressed with N oggin. Furthermore, there is no reason to believe that all family members have been identified. Of those that are known, Bmp3 is expressed in the immature somite and is down-regulated on differentiation (Dudley and Robertson 1997; J.A. M CM ahon et al., unpubl.). However, BM P3 does not appear to be re quired for normal somite patterning and has different activities from BM P2 and BM P4, so it is unlikely to be a N oggin target (K. Lyons, pers. comm.). The most plausible candidate is Bmp4, which is strongly expressed in the ventral mesoderm immediately under the paraxial mesoderm and in the coelomic mesoderm underlying the devel oping somites. In summary, our results demonstrate that elaboration of the vertebrate body plan requires not only the positive action of a number of inductive signals, but also the specific inhibition of others. It is likely that inhibitory molecules will become increasingly important in our understanding of vertebrate development as more are identified and their functions dissected.

\section{Materials and methods}

Cloning and targeting of mouse Noggin

Initially, cDN As partially encoding mouse N oggin were isolated by screening a phage $\lambda$ gt10 cDN A library (gift of Brigid Hogan) with Xenopus Noggin using standard low stringency conditions. A mouse 129 strain $\lambda$ genomic library (the generous gift of Rudolf Jaenisch, Whitehead Institute, Cambridge, MA) was screened by hybridization with a mouse Noggin CDNA probe and a single genomic clone was identified (Southern blotting confirmed that there is a single Noggin gene). The Noggin gene replacement construct was generated (see Fig. 2) by blunt end ligation of a 5', 5.2-kb, EcoRV-BstEll Noggin genomic fragment into an end-filled ( $\mathrm{T} 4$ polymerase) $\mathrm{N}$ col site in the lacZ containing plasmid, pSDKlacZ (the gift of Janet Rossant). This resulted in an in-frame fusion of the first 10 amino acids of the Noggin coding sequence with the E. coli IacZ gene containing an SV40 polyadenylation sequence. For positive sel ection, a PGKneo cassette (Soriano et al. 1991) was cloned downstream of the lacZ gene and a 3', 5.0-kb, BamHI-EcoRV homology region cloned downstream of this sel ection cassette. This targeting construct was generated in the plasmid vector pMC1-HSVTK (M ansour and Capecchi 1988) which provides a flanking herpes virus thymidine kinase gene for negative selection against nonhomologous recombinants. The targeting construct was linearized with Sall and el ectroporated into CJ7 ES cells (Swaitek et al. 1993). A clone with the expected recombination event was identified by Southern analysis using both $5^{\prime}$ and $3^{\prime}$ diagnostic probes (see Fig. 2) and this clone was used to generate germ-line chimeras. The mutated allele was maintained on an inbred $129 /$ Sv background or crossed to C57BL6/J mice to generate embryos on a hybrid background.

Identification of N oggin mutants

Initially, Noggin mutants were identified by Southern blot 
analysis of yolk sac DN A with a diagnostic $5^{\prime}$ probe (see Fig. 2). Southern hybridization to DN A digested with BamHI (5' analysis) or EcoRI ( $3^{\prime}$ analysis) with a coding region probe confirmed that the Noggin coding region was deleted from embryos that displayed a mutant phenotype. Subsequently, a PCR assay was devel oped in which amplification of the wild-type allele generated a 211-bp product (primers nogl and nog2) and ampl ification of the mutant al lele generated 160-bp product (primers nogl and gal 1). PCR samples were preheated to $93^{\circ} \mathrm{C}$ for $90 \mathrm{sec}$ then subjected to 35 cycles of amplification al ternating between a 30-sec $93^{\circ} \mathrm{C}$ denaturation and $45-\sec 72^{\circ} \mathrm{C}$ extension step (M cM ahon et al. 1992)

PCR primers: nog1, 5'-GCATGGAGCGCTGCCCCAGC-3'; nog2, 5'-GAGCAGCGAGCGCAGCAGCG-3'; gal 1, 5'-AAGGGCGATCGGTGCGGGCC-3'

\section{Histology, in situ hybridization, and cell death}

For routine histological analysis, embryos were fixed in Bouin's solution, dehydrated, paraffin embedded, sectioned at $6 \mu \mathrm{m}$, dewaxed, and either hematoxylin and eosin or toluidine blue counterstained prior to mounting. $\beta$-Galactosi dase staining and in situ hybridization were essentially as described (Wilkinson et al. 1987; Whiting et al. 1991; Wilkinson 1992). A poptotic cell death was visualized using the TUNEL procedure with a kit from Boehringer Mannheim.

\section{Explant tissue culture and RT-PCR}

M ouse psm was dissected at $9.5 \mathrm{dpc}$, embedded in collagen gels, and cultured for $24 \mathrm{hr}$ in serum-free medium; OPTI-M EM / F12/ DME (50:25:25) supplemented with $5 \mathrm{ng} / \mathrm{ml}$ FGF to promote survival in serum-free conditions (Fan and Tessier-Lavigne 1994). Forskolin was added at $90 \mu \mathrm{m}$ and IBMX at $100 \mu \mathrm{m}$ (Fan et al. 1995). Anti-SHH-N blocking antibody, 5E1 (Ericson et al. 1996) was added at $3.5 \mu \mathrm{g} / \mathrm{ml}$. Xenopus Noggin protein was purified from $\mathrm{CHOB} 3$ conditioned medium as described (Lamb et al. 1993) and was the gift of José de Jesus. SHH-N protein was the gift of Phil Beachy (Johns Hopkins Medical School, Baltimore, MD) and BMP2 and BM P4 were generously supplied by Genetics Institute. The RNA sample of each explant culture (containing two pieces of psm) was purified and $1 / 9$ of each sample was used for RT-PCR reactions in the presence of [32P]dCTP (Amersham) as described previously (Fan et al. 1995). The resulting radioactive PCR products were resolved on $6 \%$ polyacrylamide gels, dried, and exposed to X-ray films (Kodak) for $2 \mathrm{hr}$. The oligonucleotide primers used to detect Paxl and $\beta$-actin were described by Fan et al. (1995). To detect Bmp2 and Bmp4 transcripts in psm and somites, two pieces of psm and two strips of somite I-V (caudal-most five somites) were used for each culture. One half of each RNA sample was used for RT-PCR for 30 cycles $\left(94^{\circ} \mathrm{C}-60^{\circ} \mathrm{C}-72^{\circ} \mathrm{C}\right.$ cycle). The PCR products were resolved on $2 \%$ agarose gels, transferred to Gene Screen filters (NEN), hybridized with [ $\left.{ }^{32} \mathrm{P}\right] \mathrm{dCTP}$ Bmp2 and Bmp4 cDN A probes, washed under the standard high stringency condition (Sambrook et al. 1989), and exposed to X-ray films for $1 \mathrm{hr}$. The primers used were 5'-CGGAGACTCTCTCAATGGAC$3^{\prime}$ and 5'-GTTCCTCCACGGCTTCTAGT-3' for Bmp2 which generates a 436-nucl eotide product; and 5 '-CT CCCAAGAATCATGGACTG-3' and 5'-AAAGCAGAGCTCTCACTGGT-3' for Bmp4, which generates a 468-nucleotide product. Bmp2 and Bmp4 gene sequences were described by Feng et al. (1994 and 1995, respectively).

\section{Acknowledgments}

We thank the staff in our animal facility, Audrey Huang for assistance in isolating the Noggin genomic clone, Marty Shea for initial in situ hybridization analysis of Noggin expression, and Scott Lee for generously jumping in at the last minute, Lisa Brunet for the Southern analysis in Fig. 2B, José de Jesus for N oggin protein, Phil Beachy for Shh protein, Genetics Institute for BMP2 and BMP4, and Bianca Klumpar for histology. We thank the following people for gifts of probes: B. Hermann, J. Johnson, M. Goulding, T. Jessell, A. Dudley, B. Hogan, V. Pachnis, A. Joyner, H. Weintraub, E. Olson, C. Wright, P. Koopman, and G. Fischbach. Work in A.P.M 's laboratory was supported by grants from the American Cancer Society (DB 88) and N ational Institutes of Health (NIH). Work in R.M.H.'s laboratory was supported by NIH grant GM 49346. S.T. was supported by a long-term fell owship from the Human Frontier Science Program (HFSP) and L.B.Z. by a National Research Service Award (N RSA) fellowship from N IH. C.M .F. is supported by the A rnold and $M$ abel Beckman Foundation and the Alfred P. Sloan Foundation.

The publication costs of this article were defrayed in part by payment of page charges. This article must therefore be hereby marked "advertisement" in accordance with 18 USC section 1734 solely to indicate this fact.

\section{References}

Albano, R.M., R. Arkell, R.S.P. Beddington, and J.C. Smith. 1994. Expression of inhibin subunits and follistatin during postimplantation mouse development: Decidual expression of activin and expression of follistatin in primitive streak, somites, and hindbrain. Development 120: 803-813.

Arkell, R. and R.S.P. Beddington. 1997. BM P-7 influences pattern and growth of the developing hindbrain of mouse embryos. Development 124: 1-12.

Basler, K., T. Edlund, T.M. Jessell, and T. Yamada. 1993. Control of cell pattern in the neural tube: Regulation of cell differentiation by dorsalin-1 a novel TGF $\beta$ family member. Cell 73: 687-702.

Beddington, R.S.P. 1994. Induction of a second neural axis by the mouse node. Development 120: 613-620.

Brand-Saberi, B., J. Wilting, C. Ebensperger, and B. Christ. 1996. The formation of somite compartments in the avian embryo. Int. J. Dev. Biol. 40: 411-420.

Brunet, L.J., J. McM ahon, A.P. McM ahon, and R.M. Harland. 1998. N oggin, cartilage morphogenesis and joint formation in the mammalian skeleton. Science (in press).

Chiang, C., Y. Litingtung, E. Lee, K.E. Young, J.L. Corden, H. Westphal, and P.A. Beachy. 1996. Cyclopia and defective axial patterning in mice lacking Sonic hedgehog gene function. Nature 383: 407-413.

Cossu, G., S. Tajbakhsh, and M. Buckingham. 1996. How is myogenesis initiated in the embryo? Trends Genet. 12: 218223.

Currie, P.D. and P.W. Ingham. 1996. Induction of a specific muscle cell type by a hedgehog-like protein in zebrafish. Nature 382: 452-455.

Dale, J.K., C. Vesque, T.J. Lints, T.K. Sampath, A. Furley, J. Dodd, and M. Placzek. 1997. Cooperation of BM P7 and SH H in the induction of forebrain ventral midline cells by the prechordal plate. Cell 90: 257-269.

DeRobertis, E.M . and Y. Sasai. 1996. A common plan for dorsoventral patterning in Bilateria. Nature 380: 37-40.

Dickenson, M.E., R. Krumlauf, and A.P. M CM ahon. 1994. Evidence for a mitogenic effect of Wnt-1 in the developing mammalian central nervous system. Development 120: 1453-1471. 
Dudley, A.T. and E.J. Robertson. 1997. Overlapping expression domains of bone morphogenetic protein family members potentially account for limited tissue defects in BM P-7 deficient embryos. Develop. Dyn. 208: 349-362.

Echelard, Y., G. Vassileva, and A.P. M cM ahon. 1994. Cis-acting regulatory sequences governing Wnt-1 expression in the developing mouse CN S. Development 120: 2213-2224.

Ericson, J., S. M orton, A. Kawakami, H. Roelink, and T.M. Jessell. 1996. Two critical periods of sonic hedgehog signaling required for specification of motor neuron identity. Cell 87: 661-673.

Ericson, J., P. Rashbass, A. Schedl, S. Brenner-Morton, A. Kawakami, V. van Heyningen, and J. Briscoe. 1997. Pax6 controls progenitor cell identity and neuronal fate in response to graded Shh signaling. Cell 90: 169-180.

Fan, C.-M. and M. Tessier-Lavigne. 1994. Patterning of mammalian somites by surface ectoderm and notochord: Evidence for sclerotome induction by a hedgehog homolog. Cell 79: 1175-1186.

Fan, C.-M., J.A. Porter, C. Chiang, D.T. Chang, P.A. Beachy, and M. Tessier-Lavigne. 1995. Long-range sclerotome induction by sonic hedgehog: Direct role of the amino-terminal cleavage product and modulation by the cyclic AMP signaling pathway. Cell 81: 457-465.

Fan, C-M., C.S. Lee, and M. Tessier-Lavigne. 1997. A role for WNT proteins in induction of the dermomyotome. Devel. Biol. 191: 160-165.

Feng, J.Q., M.A. Harris, N. Ghosh-Choudhury, M. Feng, G.R. Mundy, and S.E. Harris. 1994. Structure and sequence of mouse bone morphogenetic protein-2 gene (BM P-2): Comparison of the structures and promoter regions of BM P-2 and BM P-4 genes. Biochim. Biophys. Acta 1218: 221-224.

Feng, J.Q., D. Chen, A.J. Cooney, M.J. Tsai, M.A. Harris, S.Y. Tsai, M. Feng, G.R. Mundy, and S.E. Harris. 1995. The mouse bone morphogenetic protein-4 gene: Analysis of promoter utilization in fetal rat calvarial osteoblasts and regulation by COUP-TFI orphan receptor. J. Biol. Chem. 270: 28364-28373.

Graham, A., P. Francis-West, P. Brickell, and A. Lumsden. 1994. The signaling molecule BMP4 mediates apoptosis in the rhombencephalic neural crest. Nature 372: 684-686.

Hammerschmidt, M., M.J. Bitgood, and A.P. M cM ahon. 1996a. Protein kinase $A$ is a common negative regulator of Hedgehog signaling in the vertebrate embryo. Genes \& Dev. 10: 647-658.

Hammerschmidt, M., G. Serbedzija, and A.P. M cM ahon. 1996b. Genetic analysis of dorsoventral pattern formation in the zebrafish: Requirement of a Bmp-4 like ventralizing activity and its dorsal repressor. Genes \& Dev. 10: 2452-2461.

Hammerschmidt, M., A. Brook, and A.P. M cM ahon. 1997. The world according to hedgehog. Trends Genet. 13: 14-21.

Harland, R.M. and J.C. Gerhart. 1997. Formation and function of Spemann's organizer. Annu. Rev. Cell Devel. Biol. 13: 611-667.

Hemmati-Brivanlou, A., O.G. Kelly, and D.A. Melton. 1994. Follistatin, an antagonist of activin, is expressed in the Spe mann organizer and displays direct neuralizing activity. Cell 77: 283-295.

Johnson, R.D., E. Laufer, R.D. Riddle, and C.J. Tabin. 1994. Ectopic expression of Sonic hedgehog alters dorsal-ventral patterning of somites. Cell 79: 1166-1174.

Jones, C.M., K.M. Lyons, and B.L.M. Hogan. 1991. Involvement of bone morphogenetic protein-4 (BM P-4) and Vgr-1 in morphogenesis and neurogenesis in the mouse. Development 121: 1433-1442.

Kaufman, M.H. 1992. The atlas of mouse development Aca- demic Press, London, UK.

Kessler, D.S. and D.A. M elton. 1994. Vertebrate embryonic induction-mesodermal and neural patterning. Science 266: 596-604.

Lamb, T.M., A.K. Knecht, W.C. Smith, S.E. Stachel, A.N Economides, N. Stahl, G.D. Yancapoulos, and R.M. Harland. 1993. Neural induction by the secreted polypeptide noggin. Science 262: 713-718.

Leyns, L., T. Bouwmeister, S.-H. Kim, S. Piccolo, and E.M. De Robertis. 1997. Frz-b is a secreted antagonist of wnt signaling in the Spemann organizer. Cell 88: 747-756.

Liem, K., G. Tremml, H. Roelink, and T.M. Jessell. 1995. Dorsal differentiation of neural plate cells induced by BM P-mediated signals from epidermal ectoderm. Cell 82: 969-979.

Liem, K.F., G. Tremml, and T.M. Jessell. 1997. A role for the roof plate and its resident TGF $\beta$-related proteins in neuronal patterning in the dorsal spinal cord. Cell 91: 127-138.

Mansour, S.L.R. and M.R. Capecchi. 1988. Disruption of the proto-oncogene int-2 in mouse embryonic-derived stem cells: A general strategy for targeting mutations to non-selectable genes. Nature 336: 348-352.

Marcelle, C., M.R. Stark, and M. Bronner-Fraser. 1997. Coordinate action of BMPs, Wnts, Shh, and N oggin mediate patterning of the dorsal somite. Development 124: 3955-3963.

M atzuk, M.M., N . Lu, H. Vogel, K. Sellheyer, D.R. Roop, and A. Bradley. 1995. Multiple defects and perinatal death in mice deficient in follistatin. Nature 374: 360-363.

McM ahon, A.P., A.L. Joyner, A. Bradley, and J.A. McM ahon. 1992. The midbrain-hindbrain phenotype of Wnt-1 -/Wnt-1 ${ }^{-}$ mice results from stepwise deletion of engrailed-expressing cells by 9.5 days postcoitum. Cell 69: 581-595.

Monsoro-Burq, A.-H., D. Duprez, Y. Watanabe, M. Bontoux, C. Vincent, P. Brickell, and N. LeDouarin. 1996. The role of bone morphogenetic protein in vertebrate devel opment. Development 122: 3607-3616.

M ünsterberg, A.E., J. Kitajewski, D.A. Bumcrot, A.P. M cM ahon, and A.B. Lassar. 1995. Combinatorial signaling by Sonic hedgehog and Wnt family members induces myogenic bHLH gene expression in the somite. Genes \& Dev. 9: 2911-2922.

Nakamura, T., K. Takio, Y. Eto, H. Shibai, K. Titani, and H. Sugino. 1990. Activin-binding protein from rat ovary is follistatin. Science 247: 836-838.

Placzek, M., M. Tessier-Lavigne, T.M. Jessell, and J. Dodd. 1991. Control of dorso-ventral pattern in vertebrate neural development: Induction and polarizing properties of the floor plate. Development (Suppl. 2) 113: 105-122.

Placzek, M., T.M. Jessell, and J. Dodd. 1993. Induction of floor plate differentiation by contact-dependent, homeogenetic signals. Development 117: 205-218.

Pfaff, S.L., M. Mendel sohn, C.L. Stewart, T. Edlund, and T.M. Jessell. 1996. Requirement for LIM homeobox gene Isl-1 in motor neuron generation reveals a motor-neuron-dependent step in interneuron differentiation. Cell 84: 309-320.

Piccolo, S., Y. Sasai, B. Lu, and E.M. DeRobertis. 1996. Dorsoventral patterning in Xenopus: Inhibition of ventral signals by direct binding of chordin to BM P-4. Cell 86: 589-598.

Pourquie, O., M. Coltey, C. Breant, and N.M. LeDouarin. 1995. Control of somite patterning by signals from the lateral plate. Proc. Natl. Acad. Sci. 92: 3219-3223.

Pourquie, O., D.-M. Fan, M. Coltey, E. Hirsinger, Y. Watanabe, C. Breant, P. Francis-West, P. Brickell, M. Tessier-Lavigne, and N. Le Douarin. 1996. Lateral and axial signals involved in avian somite patterning: A role for BM P-4. Cell 84: 461471.

Reshef, R., M. Maroto, and A.B. Lassar. 1998. Regulation of dorsal somitic cell fates: BMPs and N oggin control the tim- 
ing and pattern of myogenesis. Genes \& Dev. 12: 290-303.

Rong, P.M., M.-A. Teillet, C. Ziller, and N .M . LeDouarin. 1992. The neural tube/notochord complex is necessary for vertebral but not limb and body wall striated muscle differentiation. Development 115: 657-672.

Ruiz i Altaba, A., T.M. Jessell, and H. Roelink. 1995. Restriction to floor plate induction by hedgehog and winged helix genes in the neural tube of frog embryos. Mol. Cell. Neurosci. 6: 106-121.

Sambrook, J., E.F. Fritsch, and T. Maniatis. 1989. Molecular cloning: A laboratory manual, 2nd ed. Cold Spring Harbor Laboratory Press, Cold Spring Harbor, NY.

Sasaki, H. and B.L.M. Hogan. 1994. HNF-3 $\beta$ as a regulator of floor plate development. Cell 76: 103-115.

Sasai, Y., B. Lu, H. Stei nbeisser, D. Geissert, L.K. Gont, and E.M . DeRobertis. 1994. Xenopus chordin: A novel dorsalizing factor activated by organizer specific homeobox genes. Cell 79: 779-790.

Sasai, Y., B. Lu, H. Steinbeisser, and E.M. De Robertis. 1995. Regulation of neural induction by the Chd and Bmp-4 antagonistic patterning signals in Xenopus. Nature 376: 333336.

Schoenwolf, G.C. and J.L. Smith. 1990. Mechanics of neuralation: Traditional viewpoint and recent advances. Development 109: 243-270.

Schulte-M erker, S., K.J. Lee, A.P. McMahon, and M. Hammerschmidt. 1997. The zebrafish organizer requires chordino. Nature 387: 862-863.

Schultheiss, T.M., J.B.E. Burch, and A.B. Lassar. 1997. A role for bone morphogenetic protein in the induction of cardiac myogenesis. Genes \& Dev. 11: 451-462.

Shimamura, K., D.J. Hartigan, S. M artinez, L. Puelles, and J.L.R. Rubenstein. 1995. Longitudinal organization of the anterior neural plate and neural tube. Development 121: 3923-3933.

Smith, W.C. and R.M. Harland. 1992. Expression cloning of nog gin, a new dorsalizing factor local ized to the Spemann organizer in Xenopus embryos. Cell 70: 829-840.

Smith, W.C., A.K. Knecht, M. Wu, and R.M. Harland. 1993. Secreted noggin protein mimics the Spemann organizer in dorsalizing Xenopus mesoderm. Nature 361: 547-549.

Soriano, P., C. Montgomery, R. Geske, and A. Bradley. 1991. Targeted disruption of the $\mathrm{C}$-src proto-oncogene leads to osteopetrosis in mice. Cell 64: 693-702.

Swaitek, P.J. and T. Gridley. 1993. Perinatal lethality and defects in hindbrain development in mice homozygous for a targeted mutation of the zinc finger gene Krox20. Genes \& Dev. 7: 2071-2084.

Tanabe, Y. and T.M. Jessell. 1996. Diversity and pattern in the developing spinal cord. Science 274: 1115-1123.

Teillet, M.-A. and N.M. Le Douarin. 1983. Consequences of neural tube and notochord excision on the development of the peripheral nervous system in the chick embryo. Dev. Biol. 98: 192-211.

Valenzuela, D.M., A.N. Economides, E. Rojas, T.M. Lamb, L. N uñez, P. Jones, N.Y. Ip, R. Espinosa, C.I. Brannan, D.J. Gilbert, N.G. Copel and, N.A. Jenkins, M.M. LeBeau, R.M. Harland, and G.D. Yancopoulos. 1995. Identification of mammalian noggin and its expression in the adult nervous system. J. Neurosci. 15: 6077-6084.

Van Straaten, H.W.M. and J.W.M. Hekking. 1991. Devel opment of the floor plate, neurons, and axonal outgrowth pattern in the early spinal cord of the notochord deficient chick embryo. Anat. Embryol. 184: 55-63.

Wang, S., M. Krinks, K. Lin, F.P. Luyten, and M. Moos. 1997. Frzb, a secreted protein expressed in the Spemann organizer, binds and inhibits Wnt-8. Cell 88: 757-766.
Weil, M., M.D. Jacobson, and M.C. Raff. 1997. Is programmed cell death required for neural tube closure? Curr. Biol. 7: 281-284.

Whiting, J., H. M arshall, M. Cook, R. Krumlauf, P.W.J. Rigby, D. Stott, and R.K. Allemann. 1991. Multiple spatially specific enhancers are required to reconstruct the pattern of Hox 2.6 gene expression. Genes \& Dev. 4: 180-189.

Wilkinson, D.G. 1992. Whole mount in situ hybridization of vertebrate embryos. In In situ hybridization: A practical approach (ed. D.G. Wilkinson), pp. 75-83. IRL Press, Oxford, UK.

Wilkinson, D.G, J.A. Baile, and A.P. McMahon. 1987. Expression of the proto-oncogene int-1 is restricted to specific neural cells in the developing mouse embryo. Cell 50: 79-88.

Winnier, G., M. Blessing, P.A. Labosky, and B.L.M. Hogan. 1995. Bone morphogenetic protein-4 is required for mesoderm formation and patterning in the mouse. Genes \& Dev. 9: 2105-2116.

Yamada, T., M. Placzek, H. Tanaka, J. Dodd, and T.M. Jessell. 1991. Control of cell pattern in the developing nervous system: Polarizing activity of the floor plate and notochord. Cell 64: 635-647.

Yamada, T., S.L. Pfaff, T. Edlund, and T.M. Jessell. 1993. Control of cell pattern in the neural tube: Motor induction by diffusible factors from notochord and floor plate. Cell 73: 673-686.

Yamashita, H., P. tenDijke, D. Huylebroeck, T.K. Sampath, M. Andries, J.C. Smith, C.-H. Heldin, and K. Miyazono. 1995. Osteogenic Protein-1 binds to activin type II receptors and induces certain activin-like effects. J. Cell Biol. 130: 217226.

Zimmerman, L.B., J.M. De Jesús-Escobar, and R.M. Harland. 1996. The Spemann organizer signal noggin binds and inactivates bone morphogenetic protein 4. Cell 86: 599-606. 


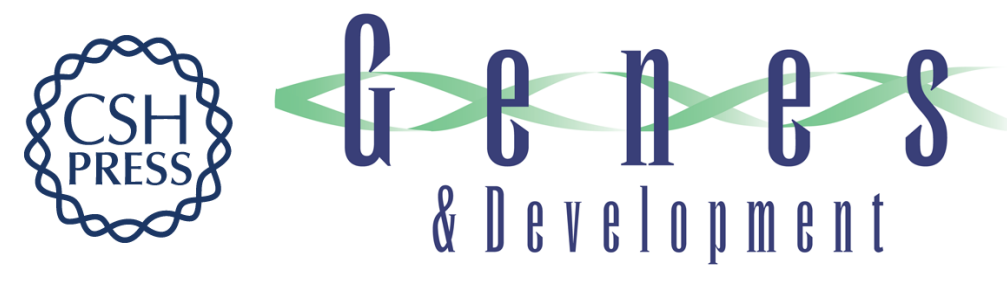

\section{Noggin-mediated antagonism of BMP signaling is required for growth and patterning of the neural tube and somite}

Jill A. McMahon, Shinji Takada, Lyle B. Zimmerman, et al.

Genes Dev. 1998, 12:

Access the most recent version at doi:10.1101/gad.12.10.1438

References This article cites 72 articles, 28 of which can be accessed free at: http://genesdev.cshlp.org/content/12/10/1438.full.html\#ref-list-1

License

Email Alerting

Receive free email alerts when new articles cite this article - sign up in the box at the top Service right corner of the article or click here.

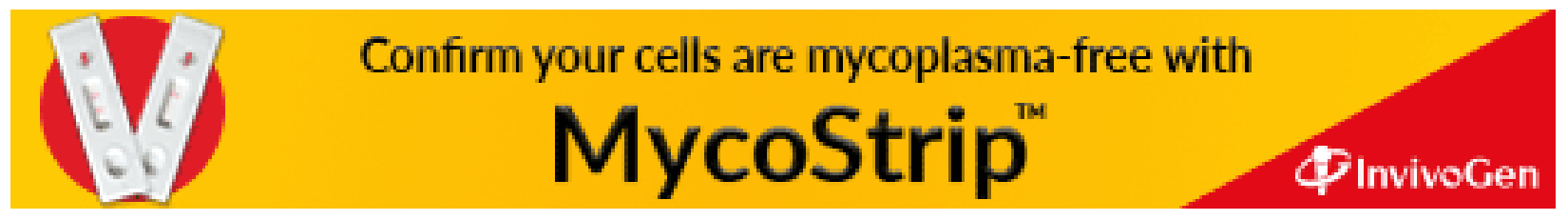

